\title{
Toward understanding the governance of varietal and genetic diversity
}

\author{
Maria K. Gerullis $^{1}$, Thomas Heckelei $^{1}$ and Sebastian Rasch $^{1}$
}

\begin{abstract}
Varietal and genetic diversity sustain modern agriculture and is provided by breeding systems. Failures in these systems may cause insufficient responses to plant diseases, which threatens food security. To avoid these failures, an understanding of the governance challenges in providing varietal and genetic diversity is required. Previous studies acknowledge the complexity of seed breeding, framing the discussion in terms of rivalry and excludability. We consider breeding systems as social-ecological systems that focus on activities that generate varietal and genetic diversity and their adaptive ability. We use an inductive approach based on qualitative methods combined with the social-ecological system framework (SESF) to depict how highly context-dependent German winter wheat breeding, multiplication, and farming activities are. Our results show that the challenges for governance lie in providing credible and symmetric information on variety performance to all actors. This is the means to steer actors into collective action by subcontracting, buying, or saving seed. Based on our application of the SESF to the German wheat breeding system, we propose to develop a more general, sectoral SESF for the sustainable governance of plant breeding by offering an adaptable template for analyses of seed systems in other contexts.
\end{abstract}

Key Words: genetic diversity; new institutional economics; plant breeding; seed production; social-ecological systems framework

\section{INTRODUCTION}

One of the greatest challenges to modern agriculture is increasing productivity while using fewer resources and reducing negative environmental impacts (Rockström et al. 2017). Plant breeding seeks to improve the crop varieties used for agriculture (Becker 2011) and has contributed to increasing yields, especially over the last 100 years (Huang et al. 2002, Evenson and Gollin 2003, Qaim 2020). Although intensification reduces land expansion, the increase in land productivity is accompanied by environmental damage through the use of chemical fertilizers, crop protection agents, and other yield-enhancing inputs (Pretty 2018). Nonetheless, plant breeding is expected to further generate landand resource-saving growth of yields, increase pest-resistance, and consequently ease the trade-off between food security and environmental impacts.

Seeds are not only an input but rather a technology shaping agricultural systems. For example, farmers will be more successful at sustaining organic cropping if their seeds are resistant to those pathogens handled by chemical crop protection agents in conventional farming (Denison 2012). Breeding systems supply farmers with a choice of seed varieties, which allows them to pick those that best fit their specific biophysical conditions (climate, soil, pest, and weed pressures), their cropping system, and other preferences. New varieties, however, need to be created, multiplied, and then sold and used on farms. A breeding system therefore contains all those activities needed for creating new varieties to be used on farms. We see the breeding system as a social-ecological system (SES); i.e., a nested, multilevel system that provides essential services to society (Berkes and Folke 1998). The essential services refers to supplying genetic material and its corresponding information flows. Genetic material refers to allelic snippets (variants of genes at gene loci), genetic traits (aggregation of specific allelic combinations), breeding lines (aggregation of genetic traits in plants over several generations), experimental cultivar variants, and varieties in the form of seed. For the purpose of our discussion, we limit ourselves to appropriating and provisioning activities of genetic material by breeders (creating new varieties), multipliers (multiplying seed), retailers (selling seed), and farmers (using the varieties in cropping).

Plant breeding is defined as "the creation, selection and fixation of superior plant phenotypes in the development of improved cultivars" (Moose and Mumm 2008:969). A plant phenotype is the observable outcome of the genetic combination of different alleles of a plant under environmental conditions. Breeders can create new varieties only if they select an improved combination of traits. However, they will be able to select this combination of traits only if there are pre-existing allelic combinations in the genes that are capable of producing the desired traits. Therefore, breeders can create a wide set of different varieties, using combinations of different traits, only if they have genetic variation in their breeding material. This is called genetic diversity. Varietal diversity refers to the variation in the set of available varieties.

Genetic and varietal diversity is crucial to maintaining or increasing yields and providing other desirable traits. Historically, epidemics of plant diseases have destroyed entire harvests and slashed yields to a minimum. The black rust epidemics in 1904 and 1916 reduced the wheat harvest in the U.S. Great Plains to one-tenth of its previous yield (Salmon et al. 1953). Governmental intervention and the existence of a few cultivars with diseaseresistance genes prevented further dramatic yield losses (Salmon et al. 1953). Today, once again, world food security is threatened by plant diseases, such as Ug99, a new strain of black rust. This can potentially lead to a global plant epidemic with most severe harvest loss if not counteracted by improving diversity in resistance traits (Singh et al. 2011).

To prevent such disasters and maintain the overall functioning of breeding systems, we need to understand the opportunities and constraints faced by breeders, farmers, and other actors in the breeding systems. These opportunities, like the information a breeder receives in exchange for planting a colleague's material in one's nursery, or how multipliers subjectively think about the 
economic potential of a variety, are affected by the institutional arrangements structuring these situations. Like Ostrom (2005:3), we understand institutions as "prescriptions that humans use to organize all forms of repetitive and structured interaction (...) at all scales". These institutions, which are classified as rules, norms, or strategies (Ostrom 2005), channel the exchange of genetic material between breeders, the varieties contracted by multipliers, and varieties used by farmers. Regulating these human activities may lead to desirable or undesirable outcomes in social and ecological performance measures; for example, whether there are enough different varieties to choose from for cultivation. Likewise, the institutional arrangements determine whether a breeder possesses the right breeding material and incentives to produce new varieties. Therefore, the challenge for actors who craft these institutions arises in designing rules and considering existing norms such that varietal and genetic diversity can be maintained over time. Given these concerns, we attempt to answer the following question: What governance challenges arise for providing varietal and genetic diversity in breeding systems?

In the next section (Breeding systems as social-ecological systems), we motivate our general approach for using an SES perspective and point to literature that analyzes governance in breeding systems. As we look at breeding systems as SESs, we outline our ontological framework to identify governance challenges in the section The social-ecological systems framework as an ontology for breeding systems. Then, based on the social-ecological system framework (SESF) (Ostrom 2009), we explain that biophysical context determines activities in breeding SESs, and present three economic transaction theories, which we employ within the SESF. In the Methods section, we explain our operationalization of the elements of the breeding systems. Our results show for the case of winter wheat breeding in Germany how producing information on biophysical processes influences activities and governance challenges thereof. Here, we present the governance challenges for providing genetic and varietal diversity in breeding, multiplying, and farm-saving seed. In our discussion, we reflect on the need for resilient seed systems. We present our hypothesis on trust and biophysical information and how this ties together with future crafting of mid-range theories and potential uses for a seed sector SESF. In our conclusion, we summarize our findings and propose further testing of our hypothesis.

\section{Breeding systems as social-ecological systems}

\section{Motivation for general approach}

We motivate the general approach addressing our research question in the remainder of this introduction. The literature on governing breeding activities frames breeding material, traits, lines, seed, or innovation in seed in terms of two attributes"subtractability" and "excludability of users" (Fig. 1). Subtractability refers to the extent to which using a good or service will reduce the availability of the good or service to others. Excludability relates to the difficulty of restricting other users from harnessing benefits of a good or service being provided. Collective goods subsume all goods and services with nontrivial cost of exclusion. These two attributes imply that resource units are merely physical subunits of a resource stock. Most researchers acknowledge that individual resource entities from plant breeding systems are multifaceted and do not fit this goods typology. They draw their readers' attention to different aspects of seed materials, such as the constructed cultural resource component of plant genetic resources (Halewood 2013), the informational component of seed breeding (Brandl et al. 2014), the public good attributes of plant breeding research (Brandl and Glenna 2017), or intellectual property rights assigned to seed developed (Godt 2016). Sievers-Glotzbach et al. (2020) provide an overview of literature on the different forms of seed commons in recent years.

Fig. 1. Typology of goods and services adapted from Ostrom (2005), including definition from Hinkel et al. (2015).

\begin{tabular}{llcc} 
& & \multicolumn{2}{c}{ Excludability of users } \\
\cline { 2 - 4 } Subtractability & Easy & Difficult \\
of use & High & Private good & Common pool resources \\
\cline { 2 - 4 } & Low & Toll or club good & Public good \\
\hline & & & Collective goods
\end{tabular}

Despite these concerns of lacking categorical fit, most studies use a good or service as the vantage point for their analyses. Hinkel et al. (2015) emphasize that no resource is rivalrous or excludable per se, but rather is dependent on the activities related to the respective resource units. For example, it is important to differentiate whether people are engaged in recreational fishing using catch-release, or if fishing is a source of food, which remove their catch from the resource system.

In breeding and farming, it is difficult to exclude stakeholders from seed saving and infinitely farm-saving seed. If the cost of exclusion from the benefits of a good or service are nontrivial, then we define these as collective goods, as in Hinkel et al. (2015). Hence, we classify seed material as collective goods, which necessitates the specification of the degree of subtractability of the good along specific activities. Each activity in an action situation should therefore be considered on its own in how it subtracts units from a resource stock. Action situation denotes the metaphorical space where activities of actors occur. For details, we refer to Poteete et al. (2010:40).

Taking an activity-focused perspective, however, opens up the possibility to (a) diagnose in what action situations subtractability is relevant, and (b) unpack the attributes adding to the underlying social dilemmas of the action situations. We show how to possibly define the resource system and resource unit context to determine how their attributes influence subtractability in action situations that provide genetic and varietal diversity.

Furthermore, the activity-focused perspective allows us to explore government options in a more differentiated manner. Formerly, an ideal form of government was associated with different kinds of goods as a panacea for failing resource management (Ostrom $2010 b$ ). Usually, a free market was deemed ideal for private goods and a hierarchical government for public goods. Yet, these ideotypes of governance prove impractical when looking at context-dependent situations like governing agricultural research for seed innovations (Brandl and Glenna 2017).

Policy-makers need a clearer idea of which activities to regulate under what conditions. Crafting effective policies needs midrange theories, which account for context but still are generalizable to 
multiple variants of the same subject of governance. For example, different kinds of breeding, such as conventional, organic, or participatory breeding (Chable et al. 2008), may exist under the same regulatory schemes. These schemes need to accommodate for breeding of fruit (Wolter and Sievers-Glotzbach 2019), vegetables (Chable et al. 2008), and grain (Gerullis 2016), although the individual types of crops pose very different challenges when being improved by breeders. To develop theories fit for effective governance, we need to provide a baseline to be capable of saying how the current systemic configuration functions. Looking at resources from the usual dichotomous perspective may lead to panacea prescriptions of governance rather than to context-dependent heuristics of governance (Darnhofer et al. 2010).

We tackle these mentioned deficits in conceptualizing the breeding system as a SES and analyze its governance challenges. We apply the SESF developed by Ostrom (2009) and McGinnis and Ostrom (2014), taking an activity-focused analytical perspective. The SESF is the only SES framework that puts equal weight on the social and ecological system (Binder et al. 2013). It was developed with a focus on sustainable outcome performance of governance-related research questions (Poteete et al. 2010, Binder et al. 2013). We want to establish a starting point for developing future midrange theories that serve the sustainable governance of breeding systems. To effectively do so, we present where the current governance challenges in seed breeding occur and how they are tackled by different coordination mechanisms in industrialized plant breeding systems.

We apply the SESF to German winter wheat breeding because it poses an instructive case: winter wheat is one of the most produced cereals worldwide and in Germany. Wheat is a self-pollinating crop, which makes it an archetype of line breeding - the most popular technology in breeding cereals throughout the last century (Becker 2011). Wheat has a high productive value for German farmers and breeders. The German wheat breeding sector comprises 21 active breeders. Thus, the case of German winter wheat lies in-between crops that are bred in a setting of high market concentration, such as maize, and small, localized breeding activities, such as legumes. We expect the case of German winter wheat to be highly instructive as a large-scale agricultural resource system with a variety of different attributes.

\section{The social-ecological systems framework as an ontology for breeding systems}

This subsection presents the ontological framing of our analysis, the SESF, and underlying premises - resilience of SESs, social dilemmas, and governance challenges. Ontology means the essence of reality (Poteete et al. 2010:216), and an ontological framework is a guide to arrange essential features of complex systems, like SESs. The SESF is used to include the underlying structure of SESs around an underlying action situation where activities are governed to solve (or not) a social dilemma. Yet, one needs theories to connect the systems' entities meaningfully.

Our premise is to treat breeding systems as SESs. Resiliencedefined as the "capacity of a system to absorb disturbance and reorganize while undergoing change so as to still retain essentially the same function, structure, identity and feedbacks" (Walker et al. 2004:4) - is the underlying desired goal. Therefore, we stress the importance of (a) maintaining the link between social and ecological systems, and (b) maintaining the defining system functions. Our research question in this context is how does the breeding system provide genetic material flows such that food and fiber for human consumption can be sufficiently supplied while maintaining ecosystem service provision from connected ecological systems? As such, the provided flows of genetic material, mainly in the form of seed, need to fit farming purposes to ensure varieties are adapted to specific ecological contexts and farming objectives.

That is, for individual cropping and breeding systems, maintenance and function is context-dependent because each cropping system has different configurations and attributes of social and biophysical entities. However, for different types of breeding systems, the capability of providing functions and the desirability of outcomes needs to be assessed (Carpenter et al. 2001). The SESF serves as a tool capable of arranging different system parts into a framework with the underlying focus on the performance of governance (Poteete et al. 2010, Binder et al. 2013).

Social dilemmas arise when individuals are tempted to take an action but the collective will be better off if all (or most individuals) take other action(s) (Poteete et al. 2010:79). As outlined, nontrivial cost arises from keeping someone from undertaking undesirable activities, termed as the cost of exclusion (Hinkel et al. 2015). Collective goods are a category of dilemmas where these costs arise from undesirable appropriation activities. If some actors overuse a resource, those activities may then reduce other actors' potential use. In its extreme form, this may lead to the unrecoverable overuse of a resource and a collapse of the resource stock. The governance challenge is to implement institutional arrangements such that (a) activities of appropriating a collective good will not overuse it, and (b) the collective good in question will be created, maintained, and improved over time. The first is a canonical appropriation action situation, while the latter signifies the canonical provision action situation (Hinkel et al. 2015). Different factors influence the core relationship of individuals solving a social dilemma. Solving a social dilemma usually entails some form of collective action or cooperation in activities of individuals. Cooperation among individuals is highly context-dependent (Poteete et al. 2010). In the SESF, we separate the context into a micro-situation, identifying attributes that directly affect individual behavior and broader social-ecological variables.

The premise for using the SESF is that we can unpack influencing factors of activities in a hierarchical manner. The SESF by design allows for using different theories within the same framework, making it possible to compare the economic coordination mechanisms currently regulating the different material and information flows within the breeding system. There are many entities, system features, interactions, and feedback loops that can be aggregated and disaggregated to concepts that influence the outcomes of activities in a SES. We assume that these variables are subsystems - one nested within the other (Simon 1996). Therefore, the SESF divides the underlying SES into different tiers.

The first tier of the SESF comprises the resource units as part of the resource system. The resource units function as inputs to the action situation, and the governance system defines rules for 
actors participating in the action situation, with interactions leading to outcomes (Ostrom 2009). The second tier is most commonly represented as an extensive list of potential subconcepts of the various first tier concepts deemed relevant for the focal action situation. These concepts can further be subcategorized into more tiers if necessary. They will contribute by explaining how the micro-situation influences the behavior of individuals. We concentrate on those governance challenges regarding the links between the social and biological domain connected to the appropriation and provision activities of the collective goods in question. Therefore, we concentrate on breeding, seed multiplying, and seed-saving/seed buying activities.

\section{Biophysical context}

The SESF has been developed for analyzing the governance of small-scale resource systems. Likewise, the design principles from Ostrom (1990) inform the sustainability of small-scale resource systems. Projects like the Social-Ecological Systems MetaAnalysis Database (SESMAD) (Cox 2014) explore sustainable governance of large-scale resource systems. Breeding systems of whole countries - as in our case-are large-scale resource systems, since they go beyond one spatially well-defined area and include several soil-climatic niches (Acquaah 2007, Cox 2014). For the sustainable governance of large-scale natural resource systems, findings and theories are not yet available to serve as design principles (Ostrom 1990). Partelow (2018) suggested aggregating insights on different resource system types into sectoral SESFs for finding the context-dependent unique yet shared variables of different natural resource types, such as fisheries or forests.

In the SESF, biophysical entities are segregated into resource system and resource units, which aggregate to a resource stock. The classic example is a fish being one unit of a fish stock, and the underwater ecology and all the technical infrastructure (e.g., fishing boats) to provide the fish is the resource system. Varietal and genetic diversity are idiosyncratic resources in the sense that they are both dependent on human activities and need to be sown, managed, and actively improved by humans. Changes in crop seed attributes will be produced only if humans actively change the nature of a plant. Degradation of varietal and genetic diversity stems from not undertaking the respective activities. Not sowing a variety will lead to the disappearance of its genetic or phenotypic traits and its loss from the common gene pool or varietal stock. Hence, seeds are biofacts (Karafyllis 2006), meaning they are biological material, a natural resource, and a (human-designed) technology at the same time.

Moreover, the "quantity" of our resource stock (pool of varieties or gene pool) is the difference in traits and not the mere number of varieties or genes present. "More" genetic material or varieties is not superior to "less" material, but whether the material at hand can satisfy the needs of human end-uses is decisive. From an economic perspective, varieties are bundles of attributes where each farmer or breeder has a unique satiation point for a specific combination of attributes compared to bundles that deviate from this ideal combination (Varian 2006). Therefore, the governance challenge for varietal and genetic diversity is to steer the community of actors to continuously use seeds such that a desirable set of traits is available despite potential individual incentives to behave otherwise.

\section{Theories of transactions}

We are not interested in the SESF as a mere descriptive collection of variables, but want to inquire about how biophysical features connect to the social system. We want to know how processes that create biophysical information influence the coordination mechanisms of human-nature transaction in the relevant action situations. We base our choice of theories about these connections on the descriptions of our interviewees and on how secondary literature frames the respective activities as (1) cooperative undertaking of material exchange between seed businesses (Gerullis 2016, Brandl and Glenna 2017; observation 1, 2, 12, 19 , $22,23)$, (2) contracting and subcontracting in seed multiplication (Thiel 2014; observation 3 and 4), and (3) "the seed market" (Brandl et al. 2014; Braun 2020; observations 1-9). We use economic theories of transaction to show the disparity in what is relevant for coordination mechanisms to function from the perspective of the economic ideal and what actors identify as relevant. This also justifies our use of the SESF, as it was designed to accommodate multiple theories in one framework and makes them comparable with respect to the scrutinized entities. Hence, we analyze the relevance of the theories in the context of the coded action situations.

We compare the theories of transaction with our observations based on Ostrom's (2010a:161) "broader theory of human behavior". Ostrom (2010a) outlines how trust and reciprocity, apart from behavior like norm adoption or learning, will lead to a higher or lower likelihood of self-organization of the actors involved in a social dilemma. As we look at activities in coordination mechanisms that allocate resources to observe how individuals deal with (potential) social dilemmas in human-nature transactions, we show how reciprocity and trust are steered within coordination mechanisms in markets, individual contracting, and collective action through social norms (Ostrom 2010a, Potetee et al. 2010).

Standard market theory assumes that prices are the only market signals driving the behavior of actors participating in transactions, and that competitive markets deliver economically efficient results (Levacic 1991). Producers and consumers are brought together in a mutually advantageous exchange of goods or services, and diverging interests are resolved through a price on which both parties agree (Callon 1999). Owing to the structure of market transactions, actors in markets are able to put their trust in the system itself rather than into other parties involved in the transactions. Because the transaction in a market is near instantaneous from the moment an individual enters the transaction to its fulfillment, there is no reciprocity or reputation building taking place in this setting. Both parties can leave the market transaction without lasting ties, as strangers to each other (Callon 1999).

Collective action gives stakeholders a chance to manage the natural resource system sustainably. It provides the option of using the resource over an infinite time horizon if they choose to bear the cost of self-organizing. Reputation, trust, and reciprocity play major roles here, where different structural variables such as the number of participants, face-to-face communication, heterogeneity of participants, or past experiences influence these three concepts and their linkages, thereby leading to different levels of cooperation. For a more extensive list of these variables, 
see Poteete et al. (2010:228-232). Natural resource systems usually bring about their resource units with a time lag and in very different forms. While in a market, all activities regarding the appropriation of goods and services can be transferred into money equivalents (Callon 1998), not everything a natural resource system produces can be calculated in one type of (metaphorical) currency. Trust and the entanglement in dependencies from other actors bridge structural and time differences of the transactions taking place. Moreover, the time lag gives actors the chance to reciprocate and frame these activities as seemingly selfless (Callon 1998), expressing trust and building more personal bonds between individuals, such as friends.

Subcontracting occupies a middle ground between market and subcontracting settings. Its time horizon is finite but not instantaneous. There is usually a time gap between the fulfillment of one party's obligation and the return of the service/good by the other party. Both individuals cannot part as strangers before both sides receive their due, but neither can they rely on a lasting bond to balance any open account. They may specify their mutual obligations in a contract, configuring every little detail of the relationship through bargaining, negotiations, and mutual adaptions (Lorenz 1991). Again, the underlying challenge is to collapse time frames and goods or services exchange into one contract, even though they are delivered with a lag and in (potentially) different forms. Such specifications, be they written or merely verbal, are however limited by the underlying transaction cost involved in bargaining, negotiation, and adaption processes. Not all actions can be sufficiently controlled or monitored, even if they are set in writing within a contract (Lorenz 1991). For the duration of a contract, the involved actors are thus neither strangers nor friends to each other but are locked into reciprocation and trust over a negotiated time horizon.

\section{METHODS}

This section lays out how data for the German winter wheat breeding sector case were gathered and how we operationalized the SESF for unpacking the micro-situations around breeding, multiplying, and seed-saving activities. We took an inductive approach in our research design (Bernard 2013) to accommodate for a wide variety of data types: (a) qualitative interviews, (b) participant observation, and (c) secondary sources from scientific literature or practical guide books on breeding, farming, and seed multiplication.

Data collection followed a grounded theory style process (Bernard 2013), as plant breeding is very heterogenous in terms of explicit and implicit knowledge (Timmermann 2009, Brandl et al. 2014). Strauss and Corbin (1994:276) state that "the methodology's central feature is that its' [sic] practitioners can respond to and change with the times (...), as conditions that affect behavior change, they can be handled analytically". We conducted qualitative, initially open and later semi-structured interviews with open questions. To avoid misrepresentation of individual attitudes and viewpoints, interviewees' claims were anonymized, fed into modified questionnaires, and then presented to subsequent interviewees for comment. Through this iterative approach, we consolidated individual perspectives into a knowledge consensus of the plant breeding community. To account for survivor bias and sequentiality, these consolidated accounts were presented to the first round of interviewees for validation in a final feedback loop. Interviews were conducted throughout 2016-2017, with revisits on selected topics in 2019, on four occasions (see Appendix 2, Table A2.1 for a detailed listing of topics). During the 2019 round, we sought mainly to update information in the face of changes in the industry (pathogen disease events, merges and acquisitions, business trends) and to complete information missing from earlier accounts. Our 18 interviews were complemented by participant observations on 21 occasions (see also Appendix 2, Table A2.1). We used participant observation to supplement our interview data with practical, firsthand experience of processes in breeding programs (Bernard 2013). All quotations were translated from German into English.

Interviews and participant observations are numbered in brackets following each paragraph. Information on retailing and multiplication was drawn from secondary and legal sources as suggested by Cox (2015) to complement case study work on SESs. Our initial access to winter wheat breeding came from contacting two private wheat breeding firms: a southern Bavarian cereal breeder and the other from Lower Saxony in northern Germany. This allowed us to sample further interview partners in both regions through snowballing (Bernard 2013). Because southern Germany has smaller spatial segments in its ecological niches compared to northern Germany, we wanted to account for potential differences.

There is less market concentration in German winter wheat breeding compared to other crops such as maize or rapeseed (Brandl and Glenna 2017). German plant breeding is done by 58 different private businesses that produce commercial seed, of which 21 have winter wheat programs. Public research centers support German agricultural extension to farmers and conduct research projects with breeders. The Federal Research Centre for Cultivated Plants and the Bavarian State Research Center for Agriculture are prominent actors at the federal and state level, respectively. Both institutions support public plant breeding through public-private partnerships (Brandl et al. 2014). The employees of governmental organizations are usually referred to as "public breeders", although producing new varieties is not their main goal. Instead, they provide public infrastructure for variety trials and pre-breeding programs.

Interview transcripts were initially coded openly (Bernard 2013). In the subsequent step, we used the diagnostic procedure by Hinkel et al. (2015) to determine underlying social dilemmas and the different entities of the SES to ensure comparability with other SESF cases. These codes were conceptually matched with the SESF variables, for which the results can be seen in Figs. 2-4 for the first tier and in Appendix 1, Figs. A1.1-1.3 for the second tier. Hinkel et al. (2015) provide a set of 10 questions to identify and interpret the different attributes of the units of the resource (RU) and their providing resource systems (RS) together with the action situation and governance system (GS) from the SESF. RU and RS were codified as suggested by Hinkel et al. (2015) to characterize governance challenges in relation to two types of action situations: one is a provisioning action situation in which certain actors face the collective challenge to maintain, create, or improve the collective good; the other is an appropriation action situation in which actors face the collective challenge to avoid overuse of a collective good. We use the identified actor groups, $\mathrm{RU}$ stocks, and RSs in the following for representing the first tiers 
Fig. 2. First-tier social-ecological system framework components for provisioning and appropriating genetic diversity.

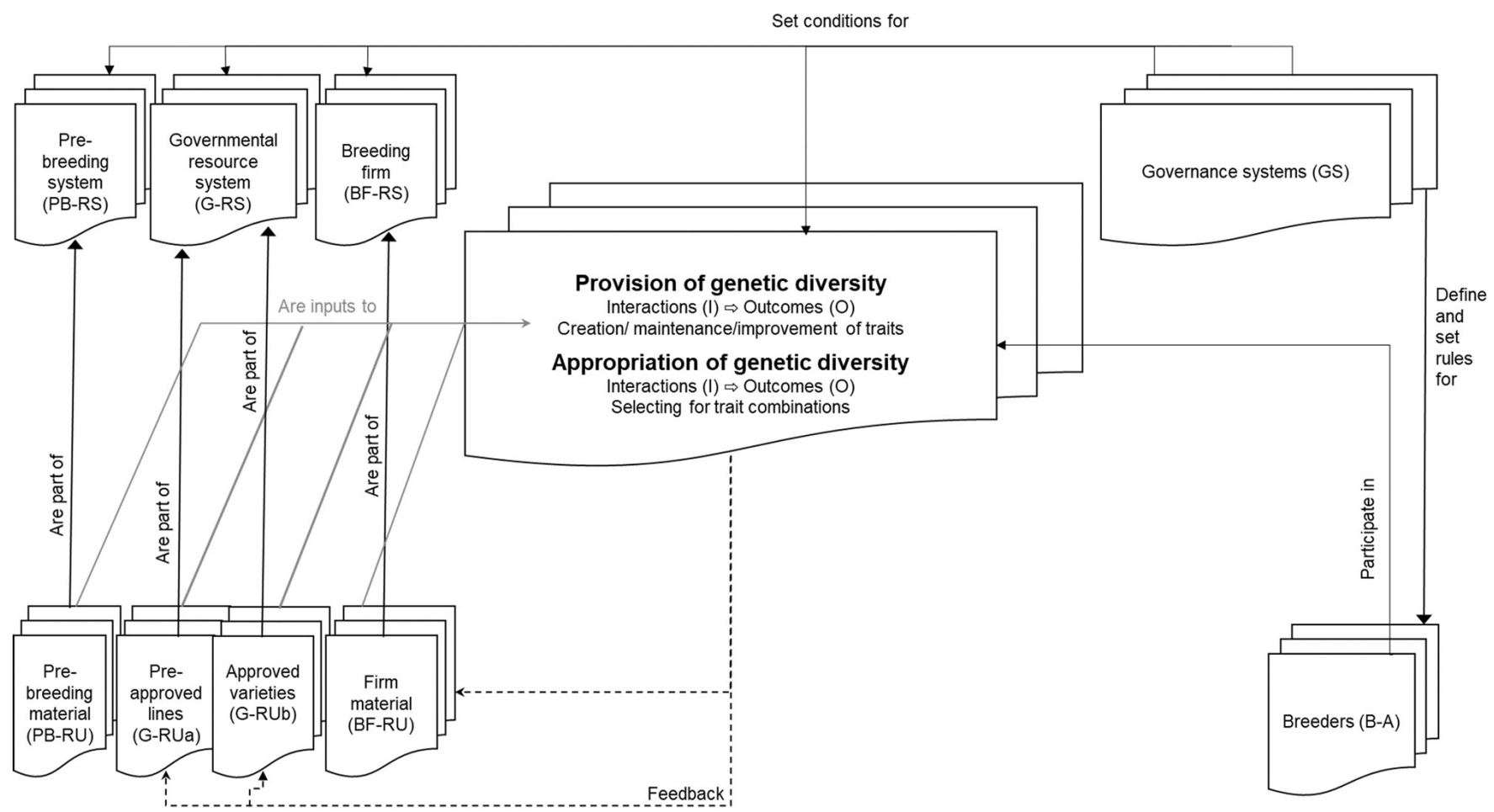

First-tier variables are taken from McGinnis and Ostrom (2014), with alternative variables for governance system. Because there are multiple resource systems with resource units and actor groups, these variables are preceded by an abbreviation for the respective group. Social, economic, and political settings and related ecosystems are not accounted for because they were not found to be relevant for the investigated level of analysis. Relevant sources for the included variables were mainly interviews $1,2,3,7,8,10,12-15,17-20,22,24-30$, and 32; see Table A2.1.

of the SESF in breeding, multiplication of seed, and appropriating seed by seed-saving or seed buying (Figs. 2, 3, and 4 , respectively).

There are shortcomings to our approach. Our sampling through snowballing from those breeders in our vicinity may have introduced a bias to a certain degree, as we were not able to interview breeders from one of the firms dominating the international seed market, such as Bayer Crop Science or Syngenta. Moreover, the heterogeneity of the data posed a challenge in terms of integrating them into the SESF, and would not have worked without Hinkel et al. (2015). Yet, we are still missing a proper diagnosis to operationalize the GS variables of the SESF in correspondence to the RS.

\section{RESULTS}

This section presents the results of using the SESF for German winter wheat breeding. We present the governance challenges arising from breeding, multiplying, and using seed for farming. The three action situations show how social dilemmas in breeding systems depend on how information on biophysical context is created and distributed. In Fig. 5, we provide an overview of the main activities in the breeding system, comparable to the examples provided in Hinkel et al. (2015). Fig. 5 shows which and how different activities contribute to the two outlined provisioning situations. Each activity-to-RU relationship yields different levels of subtractability.
In this section, terms in parentheses refer to variables or entities in Figs. 2, 3, 4, or 5. Second-tier SESF variables-also in parentheses - are preceded by two letters that indicate the corresponding entity they refer to in the corresponding first tier. They can be found in Appendix 1, Fig. A1.1 for appropriating and providing genetic diversity, Fig. A1.2 for providing varietal diversity, and Fig. A1.3 for appropriating varietal diversity.

Varietal diversity is crucial to the farming system because the available variation enables farmers (F-A) to choose the variety appropriate for their needs. The main benefits to farmers from cropping a variety are the security and income derived from stable and high yields over the years. In Germany, farmers will buy varieties listed on the Descriptive Variety List from agricultural retailers (R-A) if they do not save seed on their own. Breeders subcontract rights to multiply varieties to multipliers and retailers through different licensing relationships, involving marketing organizations and other governing actors (GS). Breeders (B-A) and multipliers earn income through license fees from selling varieties to farmers. For retailers, seeds are merely one input among others sold to farmers. Breeders have a future value from a diverse gene pool available for their breeding activities. Breeders supply the initial material from which multipliers propagate the marketed seed (M-RU). In Germany, breeders receive licensing fees for sales of certified seed and for farm-saved seed (F-RU), which farmers voluntarily pay to a (private) governing organization, called Saatguttreuhand, which reimburses breeders for these seeds [1, 3, 4, 6, 11]. 
Fig. 3. First-tier social-ecological system framework components for provisioning varietal diversity.

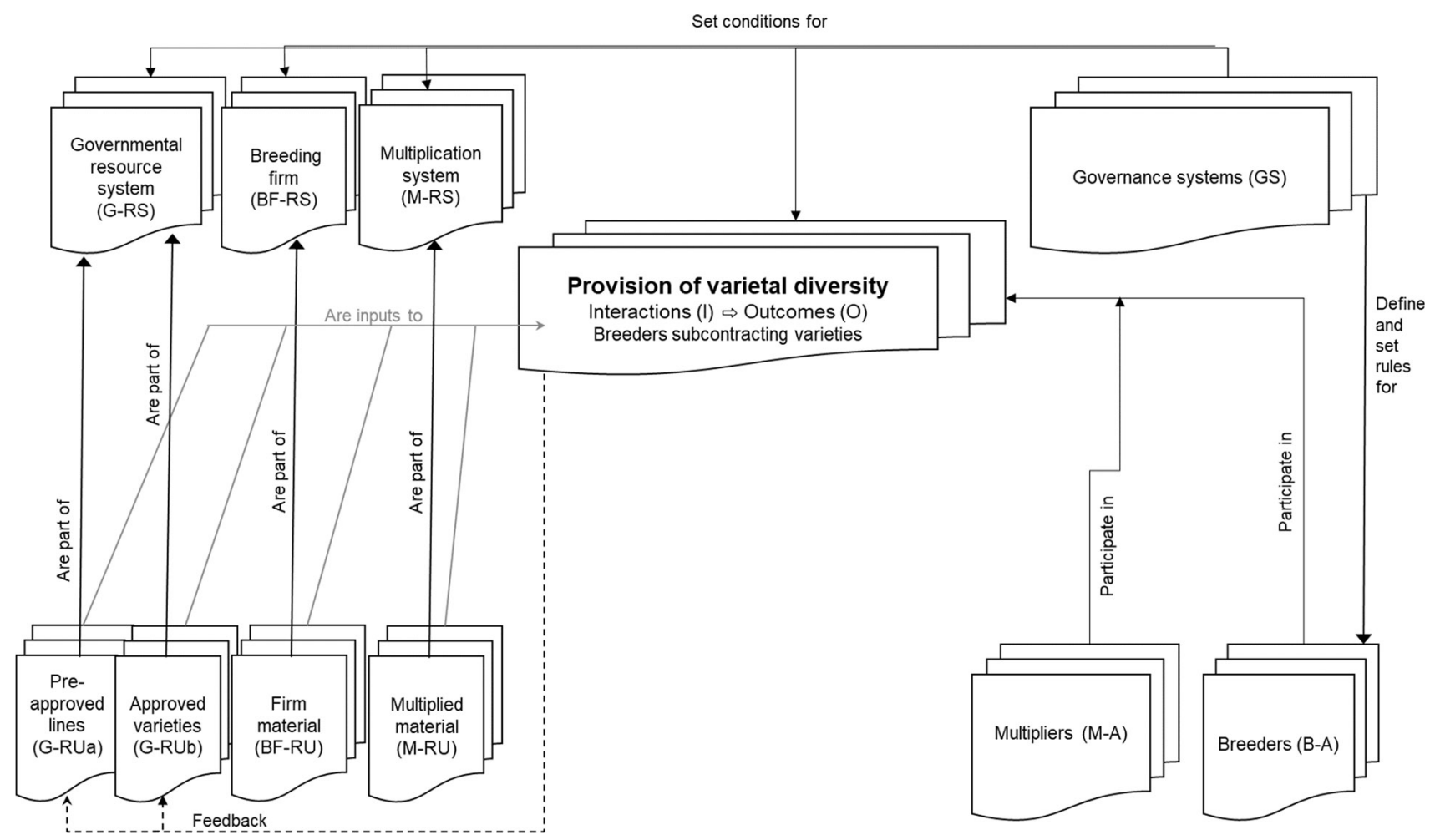

First-tier variables are taken from McGinnis and Ostrom (2014), with alternative variables for governance system. Because there are multiple resource systems with resource units and actor groups, these variables are preceded by an abbreviation for the respective group. Social, economic, and political settings and related ecosystems are not accounted for because they were not found to be relevant for the investigated level of analysis. Relevant sources for the included variables were mainly interviews $1,2,3,4,6,8,9,14,21,23$, and 33; see Table A2.1.

\section{Providing genetic diversity}

To develop new varieties, breeders need genetic variation in different candidate cultivars. Next, they select those candidate variants from the plots of the candidate cultivars, which are planted for inspection, with desired observable traits under different environmental and management conditions (Becker 2011) (see Fig. 2 [first-tier variables] and Appendix 1, Fig. A1.1 [second-tier variables]). Having data on agronomic traits for different genotypes is central to decision-making in plant breeding - "the data [are] key" [27]. The different input materials are marketed varieties (G-RUb), pre-approved lines (G-RUa), prebreeding material (PB-RU), and a breeding firm's own material (BF-RU). Asked whether there is a global gene pool, one breeder responded, "no no no...the gene pool is what [breeders] build up themselves, each unique to themselves - the employees and the breeders. There are breeders who always register the same variety type, because they believe that's how a variety needs to look like - their ideotype. There is a gene pool of the individual breeder, which is there. And it depends upon philosophy of the breeder how far he wants to break that up - and for what target market he is breeding for" [2]. Breeders' gene pools therefore depend heavily on their decision-making.

Breeders tackle two main types of decisions: crossing, and selecting for a targeted genetic and phenotypic variation within their material (Timmermann 2009). Depending on the size of a firm's breeding program, this potentially involves planning a hundred to several hundreds of crosses per year. Selecting variants deemed as good candidates for varieties (positive selection) or not worthwhile keeping (negative selection) means inspecting several thousand variant plots per year (Timmermann 2009). Based on the information available on agronomic performance data and its quality, breeders decide which genotypes to use for crossing and during selection (GD-I1) [1, 2, 10, 17, 18, 19, 26, 27, 28, 29, 30].

Time, nursery space, and information on material are scarce in the breeding process. Information on traits is produced by sowing, inspecting, and harvesting the different materials in different testing sites and nurseries sustained by the breeding firms (BFRS) and different governmental organizations (G-RS; PB-RS). Time is critical in breeding because it takes on average 12 years to establish a desired trait combination in a variety. The size of nurseries determines how much space there is each year for inspecting their different lines. Nurseries together with greenhouses, cooling chambers, and all other required technology elements make up the resource system's size (BF-RS3) and determine the number of candidate varieties (lines) submitted for approval. While big firms will have multiple locations around the world to test their breeding material (BF-RS9; BF-RU7b), and greenhouses, big nurseries, and the newest technological setup (BF-RS4; B-A9), small- and medium-sized breeders lack capital for such equipment, thereby leading to heterogeneity among 
Fig. 4. First-tier social-ecological system framework components appropriating varietal diversity.

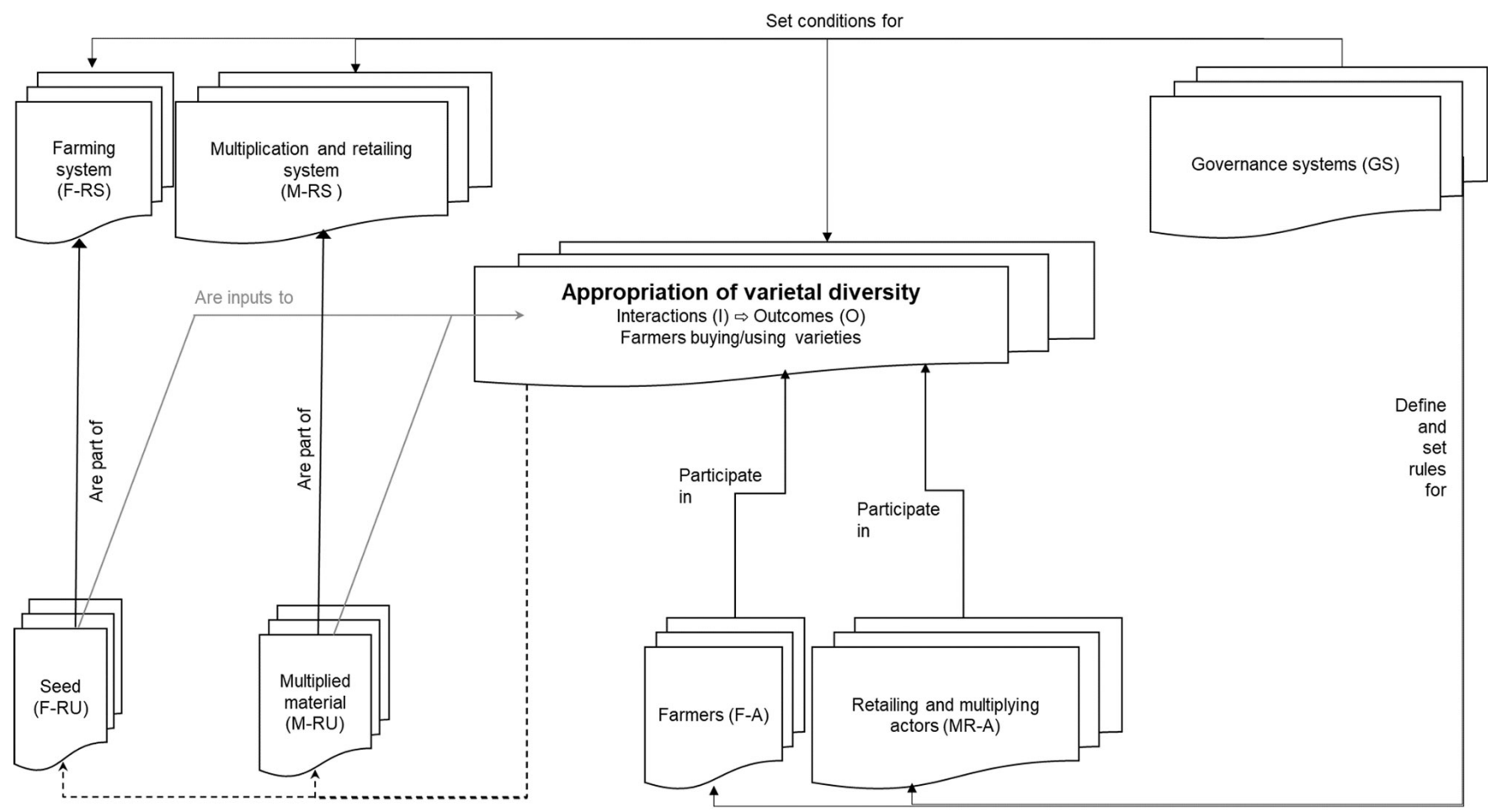

First-tier variables are taken from McGinnis and Ostrom (2014), with alternative variables for governance system. Because there are multiple resource systems with resource units and actor groups, these variables are preceded by an abbreviation for the respective group. Social, economic, and political settings and related ecosystems are not accounted for because they were not found to be relevant for the investigated level of analysis. Relevant sources for the included variables were mainly interviews $4,5,9,11,8,16,21,23,31$, and 33; see Table A2.1.

actors in their socioeconomic attributes (B-A2) $[1,2,10,26,27$, $28,29,30,12,13,14,15]$.

Breeders employ different strategies to increase their selection pressure. One is to have multiple nursery sites to test breeding material throughout the year. Multiple testing sites can gather rich data on variation in cultivar performance under different biotic and abiotic conditions (Becker 2011). Another strategy is to exchange information (GD-I2a), material (GD-I2b), and nursery space (GD-I2c) at different sites with colleagues or to cooperate in research projects (GD-I5) [1, 2, 29, 30].

In anticipation of the spread of public information, breeders will share their information and material on a bilateral basis before they are obliged to do so by law. Breeders usually have bilateral contracts with their colleagues that give each other access to their pre-approved material (G-RUa), which gives them the opportunity to cross-in material of colleagues 1 or 2 years ahead of time. This leads to a spillover of traits between different firms and spreads attractive traits throughout all firms' gene pools. Most breeding firms cooperate in research projects (PB-RS) and with public breeding programs (PB-RS) to conduct research for introducing more exotic material (GD-I7/8). These projects give breeders the opportunity to circumvent lengthy and costly screening and back-crossing activities with non-adapted material, the so-called pre-breeding material (PB-RU). It can take up to 30 years until certain traits of genetically distant material are transmitted into adapted material, carry the desired traits, and exhibit the same yields as adapted varieties [1, 29, 30, 25].
Governance challenges of providing genetic diversity

The governance challenge in providing genetic diversity (GD-O2) originates in supplying and using an ample set of different genotypes to/by breeders (GD-O1; GD-I1). The potential social dilemma for genetic diversity is that no variation is left to cross with, which reduces the scope for improvements in agronomic traits. One of the interviewed breeders uttered this concern: "You know, people say - and that is actually a bit frustrating - that today there is only $5 \%$ variation left in the wheat genome [in Germany], the rest is fixed, because these are positive traits, which are the same for all varieties...and that is a considerable narrowing....Germany's [wheat] gene pool has a quite close degree of [pedigree] relationship" [2]. The underlying problem here is that breeders may mainly be crossing-in those traits that are easy to cross-in but not those traits that need more breeding effort to enter a gene pool, although they might be necessary for long-term desirable cropping systems (All-RU3; GD-O2). In cereals, "quantitative resistances against diseases [exemplify] difficult-tobreed-for traits" [24]. Quantitative resistance traits depend on multiple gene loci, and therefore will not be breached as easily by pathogens. Establishing quantitative resistance traits in combination with high yields is difficult for breeders and can be the effort of "a whole career" [1] - "40 years" [2]. It is easier to take qualitative traits with known single gene loci and cross them into one's material, aided by genetic markers. Yet, these are "easily breached" [24] by pathogens. 
Fig. 5. Overview of provisioning action situation for seed production of German winter wheat based on the diagnostic procedure from Hinkel et al. (2015).

\begin{tabular}{|c|c|c|c|c|c|c|c|}
\hline Collective Goods & Actors & Benefits & Activity & Stock of RU & Subtractability & Ressource System & $\begin{array}{l}\text { Provisioning Action } \\
\text { Situation }\end{array}$ \\
\hline \multirow{7}{*}{$\begin{array}{l}\text { Diverse set of } \\
\text { genotypes }= \\
\text { genetic diversity }\end{array}$} & \multirow{7}{*}{$\begin{array}{l}\text { Breeders } \\
\text { (B-A) }\end{array}$} & \multirow[b]{2}{*}{$\begin{array}{l}\text { Future value of a genetically } \\
\text { diverse system }\end{array}$} & \multirow[b]{2}{*}{ Pre-breeding } & Rest of primary genepool & Low & \multirow[b]{2}{*}{$\begin{array}{l}\text { Techniqual facilities and nurseries used for pre- } \\
\text { breeding } \\
\text { (BF - RS) }\end{array}$} & \multirow{6}{*}{$\begin{array}{l}\text { Breeders maintain well- } \\
\text { performing varieties, which } \\
\text { they supply, adapted to the } \\
\text { current conditions by } \\
\text { ensuring a sufficiently } \\
\text { diverse set of on-nursery- } \\
\text { genetic diversity to select } \\
\text { from }\end{array}$} \\
\hline & & & & $\begin{array}{c}\text { adapted breeding material } \\
\text { to temperate German } \\
\text { climate }\end{array}$ & Medium & & \\
\hline & & \multirow{5}{*}{$\begin{array}{l}\text { Income from licenses of Z- } \\
\text { Saatgut and income from } \\
\text { resowing licences }\end{array}$} & \multirow{3}{*}{$\begin{array}{l}\text { Creating /maintaining } \\
\text { /improving inhouse } \\
\text { variation }\end{array}$} & $\begin{array}{c}\begin{array}{c}\text { Lines submitted to trials } \\
\text { for value of cultivation and } \\
\text { use }\end{array} \\
\end{array}$ & High & \multirow{2}{*}{$\begin{array}{c}\text { Testing sites for value of cultivation and use trials; } \\
\text { machinery and other infrastructure involved in the } \\
\text { cropping process; governance expenditure used for } \\
\text { the testing; calculating power for data processing } \\
\text { (BF-RS) }\end{array}$} & \\
\hline & & & & $\begin{array}{l}\text { All available varieties on } \\
\text { Descriptive Variety List }\end{array}$ & Low & & \\
\hline & & & & $\begin{array}{l}\text { Diversity of genotypes } \\
\text { and knowledge about }\end{array}$ & High & \multirow{3}{*}{$\begin{array}{l}\text { Nurseries; machinery; laboratories anything technical } \\
\text { or subcontracted by the individual breeding firm } \\
\text { (G - RS) }\end{array}$} & \\
\hline & & & $\begin{array}{c}\text { Selecting from inhouse } \\
\text { variation }\end{array}$ & $\begin{array}{l}\text { internal lines within } \\
\text { individual breeding firm }\end{array}$ & High & & \\
\hline & & & \begin{tabular}{|c|} 
Subcontracting \\
varieties to multipliers/ \\
agricultural retailers \\
\end{tabular} & $\begin{array}{l}\text { Total expenditure of } \\
\text { agricultural retailers / } \\
\text { multipliers }\end{array}$ & High & & \multirow{9}{*}{$\begin{array}{l}\text { Multipliers / retailers supply } \\
\text { a set of varieties fitting } \\
\text { different ecological niches } \\
\text { and preferences of farmers }\end{array}$} \\
\hline \multirow{8}{*}{$\begin{array}{l}\text { Diverse set of } \\
\quad \text { varieties } \\
\quad= \\
\text { varietal diversity }\end{array}$} & \multirow[b]{2}{*}{$\begin{array}{l}\text { Multipliers } \\
\text { (M-A) }\end{array}$} & \multirow{2}{*}{$\begin{array}{l}\text { Income from sublicensing of } \\
\text { certified seed and income from } \\
\text { selling multiplied seed to } \\
\text { breeders/retailers }\end{array}$} & $\begin{array}{l}\text { Selling certified seed } \\
\text { to agricultural retailers }\end{array}$ & $\begin{array}{l}\text { Total expenditure of } \\
\text { agricultural retailers }\end{array}$ & High & \multirow[b]{2}{*}{$\begin{array}{l}\text { Farming equipment for sowing, growing, harvesting } \\
\text { seed } \\
\text { (M-RS) }\end{array}$} & \\
\hline & & & $\begin{array}{l}\text { Multiplying seed for } \\
\text { breeders }\end{array}$ & $\begin{array}{c}\text { Total expenditure of } \\
\text { breeders for licensed } \\
\text { activities }\end{array}$ & Medium & & \\
\hline & \multirow{4}{*}{$\begin{array}{l}\text { Agricultural } \\
\text { Retailers } \\
\text { (R-A) }\end{array}$} & \multirow{2}{*}{ Income from selling other inputs } & \multirow{2}{*}{$\begin{array}{l}\text { Selling certified seed } \\
\text { to farmers }\end{array}$} & Multiplied seed & \multirow{2}{*}{ High } & \multirow{4}{*}{$\begin{array}{l}\text { Storage equipment for storing and selling seed } \\
\qquad(\mathrm{M}-\mathrm{RS})\end{array}$} & \\
\hline & & & & & & & \\
\hline & & \multirow[t]{2}{*}{ Income from selling seed } & \multirow{2}{*}{$\begin{array}{l}\text { Selling fertilizers and } \\
\text { pesticides matching } \\
\text { the respective seed }\end{array}$} & Farmers total expenditure & \multirow[t]{2}{*}{ Low } & & \\
\hline & & & & All available seed & & & \\
\hline & \multirow{2}{*}{$\begin{array}{c}\text { Farmers } \\
(\mathrm{F}-\mathrm{A})\end{array}$} & Income from selling one's yield & \multirow{2}{*}{$\begin{array}{l}\text { Conventional/organic } \\
\text { winter wheat cropping }\end{array}$} & & \multirow{2}{*}{ Medium } & \multirow{2}{*}{$\begin{array}{l}\text { Farming equipment for sowing, growing, harvesting } \\
\text { seed } \\
\qquad(F-R S)\end{array}$} & \\
\hline & & $\begin{array}{c}\text { Security from stable yields over } \\
\text { the years }\end{array}$ & & Other inputs to farming & & & \\
\hline
\end{tabular}

Breeders exhibit the attributes highlighted as tentative for collective action (Ostrom 2010a). They improve, maintain, and use their material within self-organized research projects. They also set informal norms for their activities within the community. The targeted activities create new candidate varieties using the RUs under scarce space, time, person-power, and nursery locations. Inspecting material "at a colleague's nursery" [29], or even when they will inspect it for each other, means that one has more information to base one's decisions on as a breeder. Mutual trust and reciprocation in individuals (Burt et al. 1980) play vital roles here because one party needs to trust in the other to use and allocate resources toward their colleague's material "which others will exchange with you" [30] in the long run. They cooperate with each other in activities over a 45-year time horizon. They share material and corresponding information or participate and share investments in public-private research projects on costly traits. All of these activities are undertaken based on trust between the individuals and the reputation they build over time (B-A6). As such, the governance of breeding material for German winter wheat complies with collective action theory (Ostrom 2010a) [1, $2,31]$.

The German governmental system (GS) symmetrically supplies information on qualities and agronomic performances of all lines submitted for public approval (G-RUa6; G-RUb6) to all participating breeders (B-A1; GD-I2a), as a benchmark of "seeing the performance of the competition" [7], and aids in research of "hard-to-get-to" [25] traits, which may demand more breeding effort than usual crop attributes. Yet, trust is supplemented by information. Symmetric information is a key feature of the transaction relationship between breeders. The information on the cultivars' (RUs) performance of qualities and agronomic attributes are key signals to a breeder's decision process on which material to use for breeding (GD-I1) - "if I see something good in the material [of others'], I will cross it in right away" [29]. Public information provision is key because it supplies breeders with the same comparable information and facilitates early exchange of material among breeders $[1,8,24]$.

\section{Providing varietal diversity}

Providing varietal diversity depends on breeders successfully subcontracting variety multiplication (see Fig. 3 and Appendix 1, Fig. A1.2) and marketing seed to farmers (see Fig. 4 and Appendix 1, Fig. A1.3). Farmers (F-A) may sow three types of seed: farm-saved seed, certified varieties used before, and certified seed from a new variety (Heisey and Brennan 1991). The proportion of newly bought (M-RU) compared to farm-saved seed (F-RU) is called variety turnover and determines the seed demanded. Seed turnover has been between $50 \%$ and $60 \%$ for German cereals in recent years, "with increasing tendencies" [23]. Turning toward buying certified seed depends on the value-added (F-RU4) and other advantages farmers receive from using certified seed (F-A7; F-A3), such as better germination qualities or forgoing "the hustle of dressing and pilling" the respective seed themselves (AV-I3; AV-I5) [5, 16, 21, 23].

Varieties are experience goods (Nelson 1970). If the yield from a new variety is not living up to its expectation (F-RS7), there is no 
possibility to recover the damage. Farmers ideally pick those varieties that fit the biotic and abiotic circumstances of their farm (F-RS) and other preferences in yield and crop qualities (AV-O1; AV-O2). Farmers, however, may not pick optimal varieties with respect to their specific conditions. They choose varieties without resistances - sometimes because "a neighbor recommended [it]" [5,6] — and end up with applying more pesticides than necessary (Dachbrodt-Saaydeh et al. 2018), or they may have a short memory in picking their varieties because they "only consider the last year" [23]. If farmers, however, do not buy varieties with resistances, then those varieties will not have a market share big enough to be profitable for multipliers (M-RU4). Hence, multipliers abolish their multiplication (PV-I1), and the respective resistance traits will "cease from the existence" [24] of the set of varieties (PV-O1) [1, 2, 3, 6, 24, 31].

To forgo rent-seeking by retailing actors (M-A), public variety trials (G-RS) produce "unbiased"[9] information on how varieties perform in different trial locations as an orientation for farmers' variety choices (PV-I2). There is, however, a "varying supply of [public trial] information for [different] states in Germany" [9] (AV-I2). Some varieties "work well" $[1,2]$ across different soilclimatic regions and are a potentially significant source of yield and revenue (M-RU2; PV-I5). Some varieties are fit for more "specific regions" [6] - ecological niches. Varieties that perform well in a growing region (G-RS9; G-RUa) will be recommended for that soil-climate region and will be listed as such (see annual reports from the state variety trials, such as Nickl et al. 2018). State trial conductors will choose the varieties they deem fit for the individual regions, given the variety's characteristics in the national trials (G-RUb). They will for example "look at the [varieties'] performances in the diseases important for the region" [23] and then put those varieties into the state variety trials. Supply and demand of those varieties will therefore vary across different regions $[5,16,23,35,9]$.

The appropriation situation is incorporated into the provisioning situation as the economic reasoning of the multipliers in providing varieties includes expectations on what farmers will buy later on. As holders of the plant variety protection rights (GS1; GS3; GS7), breeding firms are granted the right to multiply, prepare, and market seed material for a variety ( $\$ 10$ SortSchG (1985)—Plant Breeders' Rights Act). Breeders transfer these rights to multiplication and retailing businesses in exchange of licensing fees (Erbe 2002). Variety performance in national and state trials gives multipliers a first signal of how much a variety might be worth (AV-I2; PV-I2; M-RU4). This can have detrimental effects, as "one year [of bad performance] can destroy 20 years of breeding" [23], and multipliers will not buy the respective variety. Multipliers strive to have enough seed ready for sale in time. With wheat, it will take 3-4 years (M-RU2) of propagation until a reasonable amount of seed can be supplied (M-RS5; Becker 2011:33). Multipliers try to decide on which varieties to subcontract as early as possible (M-RU7a) [1, 2, 3, 6, 9, 23].

\section{Governance challenges of providing varietal diversity}

The governance challenge for providing varietal diversity is to coordinate an adequate supply of varieties multiplied and sold to farmers that fit their ecological needs and other preferences (PVO1). For varietal diversity, the potential social dilemma is twofold. First, farmers may not choose the varieties that fit their actual needs for many different reasons, which can lead to an underuse of certain traits (AV-O1). Second, multipliers may be prone to supply only "big varieties" [5] and abolish varieties that service small ecological niches or certain traits, such as resistances, due to lower revenue potential (PV-I1) [4, 35].

Both subcontracting variety multiplication and seed markets are forms of decentral coordination. Breeders subcontract the multiplication of their varieties to multiplying and retailing actors. Information on agronomic performance and baking qualities from public variety trials serve as signals on the attractiveness of a contracted variety to the involved parties (BFRU4; M-A7). Farmers likewise take the information as signals for their decision on which variety to buy (F-A7; F-RU4; M-RU4) $[4,5,35]$.

Trust plays multiple roles in seed marketing and multiplication. Seed marketing depends heavily on the trust farmers have in trial results. Retailer and farmer are per se strangers to each other and engage only in an instantaneous transaction relationship (Callon 1999). They may not trust each other directly, but both parties trust in the market system, establishing their private property rights over seeds purchased as a commodity (GS7) and qualities guaranteed by seed regulations and monitoring of multipliers and retailers (GS1; GS3) [21, 23, 32, 4, 5, 35]. Subcontracting of a variety establishes an expedient mutual dependency between breeder and multiplier. For the length of a contract, ranging from a few to 25 years, they are neither friends nor strangers (Lorenz 1991), and both parties do not reciprocate their actions beyond the contract. Levels of trust will, however, be influenced by the information supplied by public trials [6, 8, 33, 34].

Publicly supplied trial information produces different kinds of informational settings in both action situations. It brings about informational symmetry between farmers and retailers. This status cannot be reached for breeders and multipliers because breeders will always know more about the variety subcontracted because they have more information on a variety's descendance. Yet, the increase in information through official trials will provide the multiplier with enough information to enter a subcontract. Retailers have greater incentives to sell varieties that are susceptible to pathogens because they sell complementing crop protection products. Nonetheless, breeders need to trust retailers to fairly market their varieties next to varieties from competing breeders. Trust is expedient in this situation because one actor is incapable of monitoring the activities of the other properly. Hence, they enter a mutually dependent transaction relationship.

\section{DISCUSSION}

We presented a case of three different action situations (breeding, multiplication, farming) in a breeding SES and showed how three different coordination mechanisms direct human-nature transactions of winter wheat seed. We used the SESF as a tool to operationalize the different entities in the breeding SES, to ensure a systematic procedure that enables comparison with future cases of similar systems (Cox 2014, Partelow 2018), and to employ different theories within the same ontological framework. We showed how the production and distribution of biophysical information coincides with different forms of trust affecting transactions with different time horizons. For seed systems, the commonly employed economic theories may not bring about the relevant aspects for heuristics of governance in breeding, multiplication, and farming. 
The production of biophysical information drives all coordination mechanisms involved. Where theory on markets of homogenous goods would suggest that the price is the only relevant signal, seeds prove to be a heterogenous good with limited fit to this model and to the narrative of their governance usually coming with it. Information on agronomic performance as communicated through public trial outcomes explicitly addresses this heterogeneity in seed and gives farmers, who are heterogeneous actors in heterogenous environments themselves, the possibility of finding a matching variety. Information on agronomic performances is key in stipulating actors in buying seed or seed-saving activities. Theory on collective action (Ostrom 2010a) describes processes in breeding well because it links biophysical information variables to activities. What breeding actors identify as key components of their activities converges with what theory suggests. Individual trust, reciprocity, and reputations play a vital role in breeding activities spanning long time horizons. Theory on subcontracting seems adequate in the role it attributes to expedient trust because it includes (agronomic) information signals for actors to engage in multiplying. However, further scrutiny into how subcontracting is influenced by spatial difference and the coinciding ecological niches is necessary here.

\section{A hypothesis on trust and biophysical information}

We propose that future studies examine the role trust and biophysical information play in enabling actors to coordinate their transactions involving natural resources in large-scale systems. Our hypothesis is that the credibility of information produced and the symmetry of supplied information are crucial for facilitating socially beneficial outcomes of the coordination mechanism. By informational asymmetry we refer to some participants in a transaction having more information on the resource system and units than others. The biophysical information of varieties - in wheat we consider 23 attributes commonly measured in trials (Nickl et al. 2018) - is of higher dimensionality than the price in Akerlof's (1970) classical example of the used car market. It signals the type of ecological niche the variety may fit. Therefore, our notion of symmetry or asymmetry of information refers to whole bundles of contextdependent information on varieties. Relevant for our hypothesis is whether it influences the trust relationship between the interacting individuals. Credibility of information is relevant and produced by joint public production and quality management of field trials (results over multiple locations and multiple variants). The state and federal variety trials produce unbiased information for all actors in the system. The relevant aspect for our hypothesis is whether one has trust in the process that produces the information.

Based on the information available to us, we cannot be sure whether trust in these situations works in a cumulative fashion and if different forms of trust could substitute for each other. Also, we cannot say if different forms of information each trigger different forms of trust and corresponding coordination mechanisms. If actors produce information "credibly" and supply it symmetrically, then transactions over material (in our case, seed) can be facilitated in a coordination mechanism where actors may part as strangers (Callon 1999) — in our case, a seed market. We suspect this may be due to individuals trusting in the market system rather than the individuals they trade with directly. When looking at contracting in multiplication, information supplied from an actor who has no stakes in the transaction brings about expedient trust. This type or amount of trust is sufficient to stipulate contracting between parties that initially have very asymmetric information. We suspect credible production of information can compensate for the negative effects asymmetric information would have otherwise. In an environment involving trust between the individuals engaging in the relevant activities, symmetric information distribution of simple performance measures seems unnecessary for the technical process (Braun 2020) but suffices to speed up the breeding process itself by preempting distribution of new variety material, thereby bringing about shorter innovation cycles within the whole system.

\section{Need for resilient breeding systems}

As a scientific community, we need to be capable of comparing our cases on the governance of different agricultural SESs to form a reasonable knowledge base for constructing better heuristics for their governance. Darnhofer et al. (2010) advocate that the resilience concept should be used as a heuristic for governance of agricultural systems. Others have called for predictive models as policy-informing tools for governing SESs under the premise of "resilience from what to what" (Carpenter et al. 2001). There is already ample literature on how to frame agroecosystems for farming and how to measure their resilience (Cabell and Oelofse 2012, Rasch et al. 2017). So far, breeding systems have not gained the same kind of attention. The presented governance challenges, however, show that breeding systems, although in some subunits are very similar to a farming system, are substantially different.

\section{Mid-range theories on social-ecological systems}

Nonetheless, we want to caution our readers: providing heuristics for robust governance of seed systems in the future is not achieved by merely putting variables into the SESF. We need theory to interpret the relationship of those variables. For example, if the information provided to actors needs to be of a certain type to activate or channel a coordination mechanism, such as a seed market, into a more sustainable direction, then providing additional information through public trials would have advantageous effects according to our hypothesis. If we take the production of more pest-resistant varieties, then it is vital that public trials show counterfactual variants of varieties with no pesticide application to show the reliability of the varieties' resistance traits. However, if the current system were changed to abolish or reduce the trials, this would hamper the credibility of information and thereby negatively influence the introduction of new resistant cultivars.

For developing mid-range theories (Meyfroidt et al. 2018, Cumming et al. 2020) for breeding SESs, further cases of different types of grains, legumes, fruit trees, and other crops would have to be analyzed and subsequently synthesized into a sectoral SESF for breeding systems. We propose further synthesis to produce such a sectoral SESF for the plant breeding sector; for the sake of brevity, we would call it "seed SESF". A seed SESF may highlight variables that are unique but essential for plant breeding systems in general (Partelow 2018) and develop diagnostic theories (Poteete 2010:233) to govern plant breeding successfully. Scientists may develop better heuristics for governance-as demanded by Darnhofer et al. (2010) - for breeding systems, which are easy for policy-makers and other stakeholders to use and understand. Adapting current rules, norms, and strategies to 
future challenges in breeding, with a robust knowledge of mechanisms and attributes of the complex adaptive system at hand, will be crucial for the future resilience of all agricultural systems.

\section{CONCLUSIONS}

We illustrated how the SESF can be used to analyze the different action situations of the seed-producing system. Complemented by economic theories, we identified the governance challenges arising from social dilemmas in providing varietal and genetic diversity. Our qualitative findings in conjunction with our theoretical underpinnings allow us to hypothesize on the relationship between information provisioning and trust of actors in engaging in coordinating mechanisms, which distribute the seed and breeding material.

For the German case of winter wheat, all action situations coordinate transactions of seed material and property rights. The transaction relationships depend on information on the agronomic performance of varieties, which in turn are contingent upon ecological conditions of the resource systems producing them. Producing and distributing credible information on the agronomic performance of varieties to all actors directs the activities in the breeding system. There are varying kinds of asymmetric information between the different actors (breeding) or actor groups (multiplication and farming) in the action situations. According to the employed theories in these settings, these asymmetries would lead to adverse effects in outcomes. We found, however, that the same types of governance processes facilitated different kinds of trust between the stakeholders, thereby compensating for lack of information to sustain smooth functioning of the overall system.

In subcontracting multiplication and retailing of seed, the governance challenges are to advance symmetric distribution of information between actor groups. In subcontracting, trust between the breeding firm and multiplying actors is an expedient relationship. Individuals count on the other party behaving without guile because this would lead to termination of business relationships or ex post moral hazard on both sides. In farming, no trust is necessary to facilitate buying seed. Farmers are inclined to trust the public information system on agronomic performances of varieties and not the retailers' recommendation. In breeding, the governance challenge of providing genetic diversity to a common pool is to symmetrically distribute public information within the group of actors-breeders - to ease collective action. Individual breeders trust each other with their breeding material, such that the relationship among them is based on the judgment of the individual and on their reputation in the community, yet, this is a lengthy process. State information provisioning speeds up the innovation processes in breeding overall.

Credible information provided by the governance system may substitute for the intensity of trust and entanglement needed to cooperate. As we see from this case, provisioning of public trial information is vital for maintaining genetic and varietal diversity in crops. While this hypothesis needs further testing on its details in other contexts of breeding, we view this insight as relevant to future regulations and public investment. For example, when we talk about allotting funding for field trials in individual states, we see that our findings would advocate for investing in these state trials, such that their quality and credibility is maintained, and information stays publicly accessible in the future.

Responses to this article can be read online at: https://www.ecologyandsociety.org/issues/responses. php/12333

\begin{abstract}
Author Contributions:
Author contributions statement according to contributor roles Taxonomy - Maria Gerullis: conceptualization; methodology; qualitative coding; writing - original draft, review; edits; visualization. Thomas Heckelei: writing - review and editing; supervision; funding acquisition. Sebastian Rasch: writing - review and editing; supervision.
\end{abstract}

\section{Acknowledgments:}

We thank our interview partners and practitioners for sharing their knowledge and years of experience with us. We would like to express our gratitude to our colleagues at an IASC workshop, a virtual IASC summer school in 2020, and from the IASC ECN. We especially thank Insa Theesfeld, Edella Schlager, Marty Anderies, and Hita Unnikrishnan together with two anonymous reviewers and editor Marco Janssen for taking the time to give valuable feedback and comments for adjustments. This study was partially funded by the Deutsche Forschungsgemeinschaft (DFG, German Research Foundation) under Germany's Excellence Strategy - EXC 2070 390732324-PhenoRob and the Bundesministerium für Bildung und Forschung ( BMBF-Federal Ministry for Education and Research) Project AWECOS - 031A353. Moreover, we want to thank the $A W E C O S$ project team for their rich interdisciplinary experience and Veit Braun for enduring support on qualitative methodology development.

\section{Data Availability:}

Because the field notes and other case material cannot in their entirety be anonymized or pseudonymized, they will not be available for sharing. We encourage interested readers to contact the corresponding author, M.K.G., to discuss the article content and qualitative coding procedures. All three authors are employed by a publicly funded German University and must comply with General Data Protection Regulation (EU) $2016 / 679$ and German data protection standards. The concrete processes and regulations of the University of Bonn apply here and can be requested from the data protection office of the University of Bonn (https://www. datenschutz.uni-bonn.delde).

\section{LITERATURE CITED}

Acquaah, G. 2007. Principles of plant genetics and breeding. Blackwell Publishing, New Jersey, USA. https://doi. org/10.1002/9781118313718

Akerlof, G. A. 1970. The market for "lemons": quality uncertainty and the market mechanism. Quarterly Journal of Economics 84 (3):488-500. 
Becker, H. 2011. Pflanzenzüchtung. UTB, Stuttgart, Germany.

Berkes, F., and C. Folke. 1998. Linking social and ecological systems: management practices and social mechanisms for building resilience. Cambridge University Press, Cambridge, UK.

Bernard, H. R. 2013. Social research methods: qualitative and quantitative approaches. Sage, Thousand Oaks, California, USA.

Binder, C. R., J. Hinkel, P. W. G. Bots, and C. Pahl-Wostl. 2013. Comparison of frameworks for analyzing social-ecological systems. Ecology and Society 18(4):26. https://doi.org/10.5751/ ES-05551-180426

Brandl, B., and L. Glenna. 2017. Intellectual property and agricultural science and innovation in Germany and the United States. Science, Technology, \& Human Values 42(4):622-656. https://doi.org/10.1177/0162243916675954

Brandl, B., K. Paula, and B. Gill. 2014. Spielarten des Wissenskapitalismus: Die Kommodi?zierung von Saatgut in den USA und in Deutschland. Leviathan 42(4):539-572. https://doi. org/10.5771/0340-0425-2014-4-539

Braun, V. 2020. Holding on to and letting go of seed: quasicommodities and the passage of property. Journal of Cultural Economy 1-13. https://doi.org/10.1080/17530350.2020.1824934

Burt, R. S., K. P. Christman, and H. C. Kilburn, Jr. 1980. Testing a structural theory of corporate cooptation: interorganizational directorate ties as a strategy for avoiding market constraints on profits. American Sociological Review 45(5):821-841. https://doi. org/10.2307/2094897

Cabell, J. F., and M. Oelofse. 2012. An indicator framework for assessing agroecosystem resilience. Ecology and Society 17(1):18. https://doi.org/10.5751/ES-04666-170118

Callon, M. 1998. Introduction: the embeddedness of economic markets in economics. Sociological Review 46(1_suppl):1-57. https://doi.org/10.1111/j.1467-954X.1998.tb03468.X

Callon, M. 1999. Actor-network theory-the market test. Sociological Review 47(1_suppl):181-195. https://doi.org/10.1111/ j.1467-954X.1999.tb03488.X

Carpenter, S., B. Walker, J. M. Anderies, and N. Abel. 2001. From metaphor to measurement: resilience of what to what? Ecosystems 4(8):765-781. https://doi.org/10.1007/s10021-001-0045-9

Chable, V., M. Conseil, E. Serpolay, and F. Le Lagadec. 2008. Organic varieties for cauliflowers and cabbages in Brittany: from genetic resources to participatory plant breeding. Euphytica 164 (2):521. https://doi.org/10.1007/s10681-008-9749-7

Cox, M. 2014. Understanding large social-ecological systems: introducing the SESMAD project. International Journal of the Commons 8(2):265-276. https://doi.org/10.18352/ijc.406

Cox, M. 2015. A basic guide for empirical environmental social science. Ecology and Society 20(1):63. https://doi.org/10.5751/ ES-07400-200163

Cumming, G. S., G. Epstein, J. M. Anderies, C. I. Apetrei, J. Baggio, Ö. Bodin, S. Chawla, H. S. Clements, M. Cox, L. Egli, et al. 2020. Advancing understanding of natural resource governance: a post-Ostrom research agenda. Current Opinion in
Environmental Sustainability 44:26-34. https://doi.org/10.1016/j. cosust.2020.02.005

Dachbrodt-Saaydeh, S., J. Sellmann, J. Strassemeyer, J. Schwarz, B. Klocke, S. Krengel, and H. Kehlenbeck. 2018. Netz Vergleichsbetriebe Pflanzenschutz Zwei-Jahresbericht 2015 und 2016 Analyse der Ergebnisse der Jahre 2007 bis 2016.

Darnhofer, I., J. Fairweather, and H. Moller. 2010. Assessing a farm's sustainability: insights from resilience thinking. International Journal of Agricultural Sustainability 8(3):186-198. https://doi.org/10.3763/ijas.2010.0480

Denison, R. F. 2012. Darwinian agriculture: how understanding evolution can improve agriculture. Princeton University Press, New Jersey, USA.

Erbe, G., editor. 2002. Handbuch der Saatgutvermehrung. Agrimedia, Clenze, Germany.

Evenson, R. E., and D. Gollin. 2003. Assessing the impact of the green revolution, 1960 to 2000 . Science 300:758-762. https://doi. org/10.1126/science. 1078710

Gerullis, M. K. 2016. Entstehung privater Eigentumsrechte an Weiterentwicklungen von Weizensaat in den USA und Deutschland. Pages 235-260 in B. Brandl and S. Schleissing, editors. Biopatente: Saatgut als Ware und als öffentliches Gut. Nomos Verlagsgesellschaft, Baden-Baden, Germany. https://doi. org/10.5771/9783845275246-234

Godt, C. 2016. Geistiges Eigentumsrecht als Instrument zum Erhalt biologischer Vielfalt? Saatgut als Sonderfall. Pages 19-54 in B. Brandl and S. Schleissing, editors. Biopatente: Saatgut als Ware und als öffentliches Gut. Nomos Verlagsgesellschaft, BadenBaden, Germany. https://doi.org/10.5771/9783845275246-18

Halewood, M. 2013. What kind of goods are plant genetic resources for food and agriculture? Towards the identification and development of a new global commons. International Journal of the Commons 7(2):278-312. https://doi.org/10.18352/ijc.412

Heisey, P. W., and J. P. Brennan. 1991. An analytical model of farmers' demand for replacement seed. American Journal of Agricultural Economics 73(4):1044-1052. https://doi.org/10.2307/1242432

Hinkel, J., M. E. Cox, M. Schlüter, C. R. Binder, and T. Falk. 2015. A diagnostic procedure for applying the social-ecological systems framework in diverse cases. Ecology and Society 20(1):32. https://doi.org/10.5751/ES-07023-200132

Huang, J., C. Pray, and S. Rozelle. 2002. Enhancing the crops to feed the poor. Nature 418:678-684. https://doi.org/10.1038/ $\underline{\text { nature } 01015}$

Karafyllis, N. C. 2006. Biofakte-Grundlagen, Probleme, Perspektiven. Erwägen Wissen Ethik 17(4):547-558.

Levacic, R. 1991. Markets and governments. Pages 35-47 in G. Thompson, J. Frances, R. Levcic, and J. Mitchell, editors. Markets, hierarchies and networks: the coordination of social life. Sage, London, UK.

Lorenz, E. H. 1991. Neither friends nor strangers: informal networks of subcontracting in French industry. Pages 183-192 in G. Thompson, J. Frances, R. Levcic, and J. Mitchell, editors. 
Markets, hierarchies and networks: the coordination of social life. Sage, London, UK.

McGinnis, M. D., and E. Ostrom. 2014. Social-ecological system framework: initial changes and continuing challenges. Ecology and Society 19(2):30. https://doi.org/10.5751/ES-06387-190230

Meyfroidt, P., R. R. Chowdhury, A. de Bremond, A. Ellis, E. C. Erb, K. H. Filatova, et al. 2018. Middle-range theories of land system change. Global Environmental Change 53:52-67. https:// doi.org/10.1016/j.gloenvcha.2018.08.006

Moose, S. P., and R. H. Mumm. 2008. Molecular plant breeding as the foundation for 21 st century crop improvement. Plant Physiology 147(3):969-977. https://doi.org/10.1104/pp.108.118232

Nelson, P. 1970. Information and consumer behavior. Journal of Political Economy 78(2):311-329. https://doi.org/10.1086/259630

Nickl, U., L. Huber, A. Wiesinger, T. Eckl, and M. Schmidt. 2018. Versuchsergebnisse aus Bayern 2017 Faktorieller Sortenversuch Winterweizen. Landessortenversuch Winterweizen.

Ostrom, E. 1990. Governing the commons: the evolution of institutions for collective action. Cambridge University Press, Cambridge, UK.

Ostrom, E. 2005. Understanding institutional diversity. Princeton University Press, New Jersey, USA.

Ostrom, E. 2009. A general framework for analyzing sustainability of social-ecological systems. Science 325 (5939):419-422. https://doi.org/10.1126/science.1172133

Ostrom, E. 2010a. Analyzing collective action. Agricultural Economics 41:155-166. https://doi.org/10.1111/j.1574-0862.2010.00497. $\underline{\mathrm{X}}$

Ostrom, E. 2010b. Beyond markets and states: polycentric governance of complex economic systems. American Economic Review 100(3):641-672.

Partelow, S. 2018. A review of the social-ecological systems framework: applications, methods, modifications, and challenges. Ecology and Society 23(4):36. https://doi.org/10.5751/ES-10594-230436

Poteete, A. R., M. A. Janssen, and E. Ostrom. 2010. Working together: collective action, the commons, and multiple methods in practice. Princeton University Press, Princeton, New Jersey, USA. https://doi.org/10.1515/9781400835157

Pretty, J. 2018. Intensification for redesigned and sustainable agricultural systems. Science 362(6417):eaav0294. https://doi. org/10.1126/science.aav0294

Qaim, M. 2020. Role of new plant breeding technologies for food security and sustainable agricultural development. Applied Economic Perspectives and Policy 42(2):129-150. https://doi. org/10.1002/aepp.13044

Rasch, S., T. Heckelei, H. Storm, R. Oomen, and C. Naumann. 2017. Multi-scale resilience of a communal rangeland system in South Africa. Ecological Economics 131:129-138. https://doi. org/10.1016/j.ecolecon.2016.08.012

Rockström, J., J. Williams, G. Daily, A. Noble, N. Matthews, L. Gordon, H. Wetterstrand, F. DeClerck, M. Shah, P. Steduto, et al. 2017. Sustainable intensification of agriculture for human prosperity and global sustainability. Ambio 46(1):4-17. https:// doi.org/10.1007/s13280-016-0793-6

Salmon, S. C., O. R. Mathews, and R. W. Leukel. 1953. A half century of wheat improvement in the United States. Advances in Agronomy 5:1-151. https://doi.org/10.1016/S0065-2113(08)60228$\underline{X}$

Sievers-Glotzbach, S., J. Tschersich, N. Gmeiner, L. Kliem, and A. Ficiciyan. 2020. Diverse seeds - shared practices: conceptualizing seed commons. International Journal of the Commons 14(1):418-438. https://doi.org/10.5334/ijc.1043

Simon, H. A. 1996. The sciences of the artificial. MIT Press, Cambridge, Massachusetts, USA. https://doi.org/10.7551/ mitpress/12107.001.0001

Singh, R. P., D. P. Hodson, J. Huerta-Espino, Y. B. Jin, S. Bhavani, P. N. Njau, S. A. Herrera-Foessel, P. K. Singh, S. Singh, and V. Govindan. 2011. The emergence of Ug99 races of the stem rust fungus is a threat to world wheat production. Annual Review of Phytopathology 49:465-481. https://doi.org/10.1146/annurevphyto-072910-095423

Strauss, A., and J. Corbin. 1994. Grounded theory methodology. Handbook of Qualitative Research 17(1):273-285.

Thiel, W. 2014. Praxishandbuch Saatgutvermehrung. Erling, Clenze, Germany.

Timmermann, M. 2009. Der Züchterblick: Erfahrung, Wissen und Entscheidung in der Getreidezüchtung. Shaker.

Varian, H. R. 2006. Intermediate microeconomics: a modern approach. WW Norton \& Company, New York, USA.

Walker, B., C. S. Holling, S. R. Carpenter, and A. Kinzig. 2004. Resilience, adaptability and transformability in social-ecological systems. Ecology and Society 9(2):5. https://doi.org/10.5751/ ES-00650-090205

Wolter, H., and S. Sievers-Glotzbach. 2019. Bridging traditional and new commons: the case of fruit breeding. International Journal of the Commons 13(1):303-328. https://doi.org/10.18352/ ijc.869 


\section{Appendix 1}

Figure A1.1: Second-tier SESF components for provisioning and appropriating genetic diversity in German winter wheat

\begin{tabular}{|c|c|c|c|c|c|c|c|c|}
\hline \multicolumn{2}{|c|}{$\begin{array}{l}\text { Pre-breeding system } \\
\text { (PB-RS) } †\end{array}$} & \multicolumn{3}{|c|}{$\begin{array}{c}\text { Governmental resource system } \\
(\text { G-RS) } \dagger\end{array}$} & \multicolumn{2}{|c|}{$\begin{array}{l}\text { Breeding firms resource systems } \\
\text { (BF-RS) } \dagger\end{array}$} & \multicolumn{2}{|r|}{ Governance system (GS) $\dagger$} \\
\hline PB-RS1 & $\begin{array}{l}\text { Public and private } \\
\text { seed sector }\end{array}$ & G-RS 1 & \multicolumn{2}{|c|}{ Public sector } & \multicolumn{2}{|c|}{ BF-RS1 Seed sector } & GS1 & Breeders rights \\
\hline PB-RS2 & $\begin{array}{c}\text { No clear } \\
\text { boundaries }\end{array}$ & G-RS 2 & \multicolumn{2}{|c|}{ Clear boundaries } & BF-RS2 & Heterogenous by firm & GS2 & Germany as part of EU \\
\hline PB-RS3 & Big & G-RS 3 & \multicolumn{2}{|c|}{ Testing sites } & BF-RS3† & $\begin{array}{l}\text { Heterogenous size of } \\
\text { nurseries }\end{array}$ & GS3 & All plant breeders \\
\hline PB-RS4 & $\begin{array}{l}\text { Nurseries and } \\
\text { screening facilities }\end{array}$ & G-RS 4 & \multicolumn{2}{|c|}{$\begin{array}{c}\text { Nurseries and facilities for evaluation } \\
\text { of trials }\end{array}$} & $B F-R S 4 \dagger^{\prime}$ & $\begin{array}{l}\text { Facilities for phenotypic and } \\
\text { genotypic evaluation }\end{array}$ & \multicolumn{2}{|r|}{ Democratic } \\
\hline PB-RS5 & 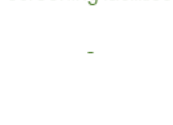 & G-RS 5 & \multicolumn{2}{|c|}{$\begin{array}{cc}\text { All Varieties on } & \text { Lines in VCU } \\
\text { DVL } & \text { testing }\end{array}$} & BF-RS5 & $\begin{array}{l}\text { Number of lines submitted } \\
\text { for approval }\end{array}$ & \multirow{2}{*}{\multicolumn{2}{|c|}{$\begin{array}{c}\text { Legislative branch of government } \\
\text { (EU-level/National legislation); } \\
\text { Lobbying organizations } \\
\text { Operational-choice rules and } \\
\text { collective-choice rules under } \\
\text { constitutional-choice rules }\end{array}$}} \\
\hline PB-RS7 & - & G-RS 7 & - & - & BF-RS7 & Fairly predictable & & \\
\hline PB-RS8 & Medium & G-RS 8 & Not existent & Not exsistent & BF-RS8 & Medium & GS7 & $\begin{array}{l}\text { Private and common property side } \\
\text { by side }\end{array}$ \\
\hline PB-RS9C & Globally spreadout & it G-RS 9 & - & $\begin{array}{l}6 \text { trial sites over } \\
\text { Germany }\end{array}$ & BF-RS9t & $\begin{array}{l}\text { Heterogenous by firm } \\
\text { locations in Germany and } \\
\text { worldwide }\end{array}$ & GS8 & $\begin{array}{l}\text { Multiple norms and strategies } \\
\text { within community }\end{array}$ \\
\hline \multirow{2}{*}{\multicolumn{2}{|c|}{$\begin{array}{l}\text { Pre-breeding Material } \\
\text { (PB-RU) } \dagger\end{array}$}} & \multicolumn{3}{|c|}{ DVL Varieties (G-RU) } & \multirow{2}{*}{\multicolumn{2}{|c|}{ Breeding Firms' Systems (BF-RU) $†$}} & \multirow{3}{*}{\multicolumn{2}{|c|}{$\begin{array}{l}\text { Breeders }(\mathrm{B}-\mathrm{A}) \dagger \\
\text { B-A1 } 19 \text { winter wheat breeders }\end{array}$}} \\
\hline & & \multicolumn{2}{|c|}{$\begin{array}{l}\text { Approved } \\
(\mathrm{G}-\mathrm{RUa}) \dagger\end{array}$} & $\begin{array}{l}\text { Pre-approved } \\
\text { (G-RUb) } \dagger\end{array}$ & & & & \\
\hline PB-RU1 & - & G-RU1 & Mobile & $\begin{array}{l}\text { Immobile with } \\
\text { exceptions }\end{array}$ & BF-RU1 & Immobile with exceptions & & \\
\hline PB-RU2 & - & G-RU2 & \multicolumn{2}{|c|}{$\begin{array}{cc}\text { Number of new } & \text { exceptions } \\
\text { varieties per } & \text { Number of submitted } \\
\text { year } & \text { lines per year }\end{array}$} & BF-RU2 & Heterogenous per firm & \multicolumn{2}{|c|}{$\begin{array}{c}\mathrm{B}-\mathrm{A} 2\rceil \\
\text { size }\end{array}$} \\
\hline $\begin{array}{l}\text { PB- } \\
\text { RU3† }\end{array}$ & High & G-RU3† & Low - medium & High & BF-RU3† & High & \multicolumn{2}{|c|}{$\begin{array}{l}\text { Experiences with own material } \\
\text { B-And varieties important for usage }\end{array}$} \\
\hline PB-RU4 & $\begin{array}{l}\text { Very high; } \\
\text { invaluable }\end{array}$ & G-RU4 & - & - & BF-RU4 & Heterogenous per variety & B-A4 & $\begin{array}{c}\text { Heterogenous locations in } \\
\text { Germany and worldwide }\end{array}$ \\
\hline PB-RU5 & Heterogenous & G-RU5 & $\begin{array}{l}\text { All varieties in } \\
\text { DVL }\end{array}$ & $\begin{array}{l}\text { Number of lines in } \\
\text { VCU testing }\end{array}$ & BF-RU5 & Heterogenous per firm & B-A5 & Enterpreneurial \\
\hline PB-RU6 & Heterogenous & G-RU6† & $\begin{array}{l}\text { Name of } \\
\text { variety; DUS } \\
\text { results }\end{array}$ & $\begin{array}{l}\text { VCU testing results of } \\
\text { lines submitted }\end{array}$ & BF-RU6 & $\begin{array}{l}\text { Labels applied within } \\
\text { nursery }\end{array}$ & B-A6† & $\begin{array}{c}\text { Partially very strong trust \& } \\
\text { reciprocity relationships }\end{array}$ \\
\hline $\begin{array}{l}\text { PB- } \\
\text { RU7b }\end{array}$ & $\begin{array}{l}\text { Programs in } \\
\text { Germany \& } \\
\text { worldwide }\end{array}$ & G-RU7b & $\begin{array}{l}\text { Spread over } \\
\text { Germany }\end{array}$ & $\begin{array}{l}\text { VCU testing sites in } \\
\text { Germany }\end{array}$ & $\begin{array}{r}\text { BF- } \\
\text { RU7b }\end{array}$ & Material within nurseries & \multicolumn{2}{|r|}{$\begin{array}{l}\text { Heterogenous mental models pe } \\
\text { A7 } \begin{array}{l}\text { breeder determined by } \\
\text { incomplete information }\end{array}\end{array}$} \\
\hline $\begin{array}{l}\text { PB- } \\
\text { RU7a }\end{array}$ & Since 1960's & G-RU7a & $\begin{array}{l}\text { Number of } \\
\text { varieties } \\
\text { approved each } \\
\text { year }\end{array}$ & $\begin{array}{l}\text { Three years of VCU } \\
\text { testing }\end{array}$ & BF-RU7a & $\begin{array}{l}\text { Each year resown according } \\
\text { to plan }\end{array}$ & B-A8 & 8 Very high resource dependent \\
\hline & & & & & & & B-A9† & Hetergenous per firm \\
\hline & & & Action situ & lations appropriation & and provi & ision of genetic diversity & & \\
\hline & & Interactio & ns (GD-I) & & & Dutcomes (GD-0) & & \\
\hline & & GD-11† & Levels of usage & e of material & & GD-01 $\dagger \quad$ Efficient us & se of ge & enetic traits \\
\hline & & GD-12a† & Information sha & ring & & Sustained & Germar & an gene pool \\
\hline & & GD-12b† & Material sharing & & & GD-03 & & \\
\hline & & GD-12c $†$ & Nursery space & sharing & & & & \\
\hline & & GD-15† & Investments in $j$ & oined R\&D projects & & & & \\
\hline & & $\begin{array}{l}\text { GD-17 / } \\
\text { GD-18 † }\end{array}$ & Networking - & mon activities & rojects & & & \\
\hline
\end{tabular}

Source: Own depiction of second-tier variables adopted from McGinnis and Ostrom (2014), with alternative variables for the governance system. As there are multiple resource systems with resource units and actor groups these variables are preceded by an abbreviation for the respective group. Individual variables not found relevant to the case are tagged with '-'. VCU denotes value of cultivation and use testing. DVL means the Descriptive Variety List. DUS denotes distinctiveness, use and stability testing. Relevant sources for the included variables were mainly interviews 1, 2, 3, 7, 8, 10, 12-15, 17-20, 22, 24-30, and 32; see list appendix 2 table 1 . † marks those variables used in the main text. 
Governmental resource system (G-RS)

$\begin{array}{ll}\text { G-RS1 } & \text { Publicsector } \\ \text { G-RS2 } & \text { Clearboundaries }\end{array}$

$$
\text { (BF-RS) }
$$$$
\text { (M-RS) }
$$

G-RS3

Testing sites and respective sites for testing available

$$
\begin{array}{lll}
\text { BF-RS1 Seed sector } & \text { PB } \\
\text { BF-RS2 } & \text { Reterogenous depending } \\
\text { on firm } & \text { PB }
\end{array}
$$

BF-RS3 Heterogenoussize of $\mathrm{PB}-$

$$
\text { nurseries }
$$

Heterogenous facilities for

G-RS4 Nurseries and facilities for evaluation of trials BF-RS4 phenotypic and genotypic PB-

evaluation RS4 Fields multiplication

G-RS5 All varieties on DVL Lines in VCU BF-RS5 Number of lines submitted PB-

G-RS7

\section{Predictable variety}

performance

\section{BF-RS7 Fairly predictable}

RS5
PB-
RS7
PB-
RS8
PB-

Propagation areafor

Heterogenous per

variety

G-RS8

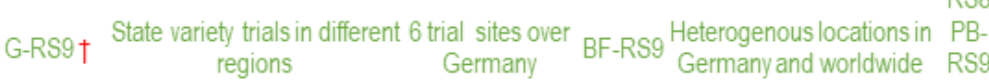

$$
\text { Medium }
$$

Hetergenous within

$$
\text { regions }
$$

$$
\text { DVL Varieties (G-RU) }
$$

$$
\begin{array}{lccc}
\text { Approved } & \text { Pre-approved } & \text { BreedingFirms' Systems (BF-RU) } & \begin{array}{c}
\text { MultipliedMaterial } \\
\text { (G-RUa) } \dagger
\end{array} \\
\text { (G-RUb) } \dagger & & \text { (MU) }
\end{array}
$$

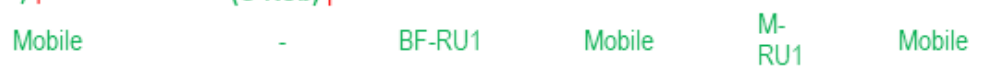

G-RU3

G-RU5 All varieties in DVL $\begin{gathered}\text { Number of linesin } \\ \text { VCU testing }\end{gathered}$ BF-RU5 Heterogenous perfirm $\begin{aligned} & \text { M- } \\ & \text { RU5 }\end{aligned} \begin{gathered}\text { Heterogenous per } \\ \text { multiplier and region }\end{gathered}$ G-RU6 Name of variety \& DUS VCU testing results BF-RU6 Variety names applied to PB- Variety names; VCU

G-RU7b

$$
\begin{aligned}
& \text { VCU testing results } \\
& \text { of lines submitted }
\end{aligned}
$$$$
\begin{array}{lr}
\text { PB- } & \text { Variety names; } \\
\text { RU6 } & \text { qualitities }
\end{array}
$$

G-RU7a Varieties approved each Three years of VCU $\begin{gathered}\text { testing } \\ \text { year }\end{gathered}$

\section{Governance system (GS)}

\section{GS1 † Breeders rights and Seed \\ $\cos$$$
\text { regulation }
$$$$
\text { Germany }
$$ \\ All plantbreeders and}

GS3 † multiplication organisation certification organisations for see

$$
\text { GS4 Democratic }
$$

GS5 Legislative branch of government

Operational-choice rules and

constitutional-choice rules

GS7 † Private property system

GS8 Multiple norms and strategies

Number of new varieties Number of submitted $\mathrm{BF}$ RU2 Hetero $M$ - Forwinter wheat the lines per year MU2† multiplication factor is per year$$
\text { BF-RU3 }
$$$$
\text { 1:40 }
$$

Predictable ifin state$$
\text { trials }
$$

BF-RU4 Heterogenous pervariety ${ }_{\mathrm{RU}}^{\mathrm{M}-}$

Heterogenous per

$$
\text { variety }
$$

$$
\text { results }
$$$$
\begin{aligned}
& \text { names } \\
& \text { lines }
\end{aligned}
$$

$$
\begin{aligned}
& \text { M- } \\
& \text { RU7b }
\end{aligned}
$$$$
\text { year }
$$$$
\text { testing }
$$

\section{Breeders (B-A)}

B-A1 19 Winter wheat breeders

B-A2 Heterogenous depending on firm

B-A3 Experiences with own material and $M-A 3$ varieties importantfor usage

B-A4

$$
\text { B-A5 }
$$$$
\text { Entrepreneuria }
$$$$
\text { B-A6 }
$$

Heterogenous mental models per B-A7breeder determined by incomplete $M-A 7$ information

B-A8 High resource dependence

\section{Interactions (PV-I)}

\section{Action situations for providing varietal diversity}

PV-11 † Levels of usage of varieties in propagation

PV-12a Public provision of information on trial results

PV-13 Heuristic deliberation of multipliers

\section{$\mathrm{PV}-01+$ Supply of diverse varieties fitting farmers preference}

$\mathrm{PV}-\mathrm{O} 2+$ Ecological Performance-outcomes of VCU and FSV trials in different regarding yield an

$\mathrm{PV}-\mathrm{O} 3$ -

\section{PV-15 † Investment in promising varieties}

PV-110 Multipliers evaluate VCU and state trials results; are being quality checked

Figure A1.2: Second-tier SESF components for provisioning varietal diversity in German winter wheat

Multipliers (M-A)

Oligopolyto polypoly

Heterogenous depending on firm

$$
\text { size and type }
$$

Experiences with kinds of
varieties sold

Located in different regions

Entrepreneurial

Mental models of SES and heuristics for devising multiplication areas

High resource dependence
Source: Own depiction of second-tier variables adopted from McGinnis and Ostrom (2014), with alternative variables for the governance system. As there are multiple resource systems with resource units and actor groups these variables are preceded by an abbreviation for the respective group. Individual variables not found relevant to the case are tagged with '-'. Relevant sources for the included variables were mainly interviews 1,2 , $3,4,6,8,9,14,21,23$, and 33 ; see list appendix 2 table $1 . \dagger$ marks those variables used in the main text. 


$$
\text { Farming system }
$$$$
\text { (F-RS) }
$$

Agricultural sector/ wheat cropping

Per farm clear boundaries

Heterogenous perfarm

\section{Fields and grain storage facilities}

$$
\text { Harvest per hectare }
$$

Dependenton biotic and abiotic factors \& variet/

$$
\text { Usually available }
$$

Spread throughout Germany

$$
\begin{gathered}
\text { Seed } \\
\text { (F-RU) }
\end{gathered}
$$

Mobile

$1 \cdot 40$ reproduction coefficient

\section{Heterogenous perfarm (EU avg 50€/ha)}

Heterogenous attributes pervariety and per field

Varieties in farmers fields

Depending on crop rotation schemes
M-RS1

\section{Seed sector}

Clear boundaries

Heterogenous

Fields multiplication, storage facilities for seed Heterogenous per propagation areafor the crop warlety

High

Heterogenous within regions

$$
\text { (M-RU) }
$$

$$
\text { Mobile }
$$

Heterogenous pervariety

\section{Heterogenous pervariety}

Heterogenous per multiplier and region

Variety names; publictrial results

Multipliers fields within regions; local storage facilities of retailers

Each year propagation according to predicted

$$
\text { demand }
$$

\section{Governance system (GS)}

\section{GS1† \\ Seed regulations}

GS2

Multiplication organizations, multiphing

GS $3 \uparrow$ farmers and certification organizations for

$$
\text { seed, all agricultural retailers }
$$

\section{GS4}

$$
\text { Democratic }
$$

Legislative branch of government

GS6 Operational-choice rules and constitutional-$$
\text { GS7 + } \quad \text { Private roice rules }
$$

\section{GS8 Multiplenoms andstages}

Figure A1.3: Secondtier SESF components appropriating varietal diversity in German winter

\section{Action situations for appropriating varietal diversity}

Interactions (AV-I)

AV-11 Varieties being bought/ farm-saved with license AV-12+ Information provided by federal/state variety trials AV-13+Deliberation on future variety performance byfarmers AV-15 + Choice offarm-saving or buying certified seed

AV-17 Networking with farmers and between farmers informs variety choice

AV-19 Farmers monitor theirvariety performance individually

AV-110 Farmers evaluate their variety performance individually

\section{Outcomes (AV-O)}

AV-01 +Sustained farming with appropriate varieties; economic and social viability of farm

AV-O2 +Farmers find appropriate variety for their biotic and abiotic circumstances

AV-O3 Externalities - agricultural system in terms of soil qualities (N), biodiversity outcomes (affected by pesticide/herbicide use), water quality

\section{Multipliers and retailers
(M-A)}

F-A1 Polypoly

M-A1

Oligopoly

F-A2 Heterogenous depending on firm size M-A2 Heterogenous depending on firm

F-A4 $\begin{gathered}\text { Spread over different regions with } \\ \text { various density }\end{gathered}$ M-A4 Located in different regions

F-A5 Entrepreneurial M-A5 Entrepreneurial

F-A6 - $M-A 6$

F-A7 farmers determined by different M-A7 Mental models of SES and heuristics and social networks M-A7 heuristics for devising

migh resource dependence
F-A9 Heterogenous perfarm M-A9
Source: Own depiction of second-tier variables adopted from McGinnis and Ostrom (2014), with alternative variables for the governance system. As there are multiple resource systems with resource units and actor groups these variables are preceded by an abbreviation for the respective group. Individual variables not found relevant to the case are tagged with '-

Relevant sources for the included variables were mainly interviews $4,5,9$, $11,8,16,21,23,31$, and 33 ; see list appendix 2 table 1 . $\dagger$ marks those variables used in the main text. 


\section{Appendix 2}

Table A2.1 Listing of interviews and participatory observations

\begin{tabular}{|c|c|c|c|c|}
\hline Number & Kind & Position / Organization / Occasion & Topic & Time \\
\hline 1 & OI & $\begin{array}{l}\text { Head of breeding program } \\
\text { (private) }\end{array}$ & Breeding business overview & Feb 16 \\
\hline 2 & OI & $\begin{array}{l}\text { Head of breeding program } \\
\text { (private) }\end{array}$ & Breeding business overview & Apr 16 \\
\hline 3 & OI & Product manager & Selling seed to multipliers & Apr 16 \\
\hline 4 & SI & Multiplying farmer / farmer & Variety choice and farming & Apr 16 \\
\hline 5 & OI & Farmer & Plant protection & Apr 16 \\
\hline 6 & $\mathrm{PO}$ & $\begin{array}{l}\text { Meeting sales management btw. } \\
\text { breeding and multiplication firm }\end{array}$ & Selling seed to farmers & Mar 17 \\
\hline 7 & $\mathrm{PO}$ & $\begin{array}{l}\text { Plant breeders' rights admission } \\
\text { meeting }\end{array}$ & $\begin{array}{l}\text { Plant breeders' rights } \\
\text { admission }\end{array}$ & Mar 17 \\
\hline 8 & $\mathrm{PO}$ & $\begin{array}{l}\text { Head of breeding program/head of } \\
\text { sales }\end{array}$ & Variety admission & Mar 17 \\
\hline 9 & OI & Public breeder & State Variety Trials & Mar 17 \\
\hline 10 & $\mathrm{PO}$ & Plant breeders in training & Plant breeding general & Apr 16 \\
\hline 11 & $\mathrm{PO}$ & Farmer & Inspecting winter wheat & Apr 16 \\
\hline 12 & OI & Public breeder & Prebreeding & Apr 16 \\
\hline 13 & $\mathrm{PO} / \mathrm{OI}$ & Public breeder & Back-crossing & Apr 16 \\
\hline 14 & PO & Public breeder & Hybrid breeding & Jun 16 \\
\hline 15 & $\mathrm{PO}$ & Plant breeders in training & Double-haploids & Jun 16 \\
\hline 16 & S & DLG-Field days & $\begin{array}{l}\text { Farming winter wheat and } \\
\text { plant protection strategies }\end{array}$ & Jun 16 \\
\hline 17 & $\mathrm{PO}$ & Public breeder & Field inspection & Jun 16 \\
\hline 18 & $\mathrm{PO}$ & Plant breeders in training & $\begin{array}{l}\text { Tubers and mutation } \\
\text { breeding }\end{array}$ & Jun 16 \\
\hline 19 & $\mathrm{PO}$ & Breeding assistant (private firm) & Crossing & Jun 16 \\
\hline 20 & $\mathrm{PO}$ & Plant breeders in training & Field inspection & Jun 16 \\
\hline 21 & $\mathrm{PO}$ & Plant breeders in training & Seed certification & Jul 16 \\
\hline 22 & $\mathrm{OI} / \mathrm{PO}$ & Public breeder & Population breeding & Jul 16 \\
\hline 23 & $\mathrm{PO}$ & $\begin{array}{l}\text { Meeting state variety } \\
\text { recommendation announcements }\end{array}$ & $\begin{array}{l}\text { State variety } \\
\text { recommendation } \\
\text { announcements }\end{array}$ & Aug 16 \\
\hline 24 & SI & $\begin{array}{l}\text { Scientific plant pathologist from a } \\
\text { University }\end{array}$ & $\begin{array}{l}\text { Resistances, farming } \\
\text { behavior and breeding }\end{array}$ & Mar 16 \\
\hline 25 & SI & Public breeder & Worldwide prebreeding & Jun 19 \\
\hline 26 & $\mathrm{PO}$ & Public breeder & Selection early generations & Jul 16 \\
\hline 27 & $\mathrm{PO}$ & $\begin{array}{l}\text { Head of breeding program } \\
\text { (private) }\end{array}$ & Planning of crosses & Feb 17 \\
\hline 28 & $\mathrm{PO}$ & Public breeder & Field inspection prebreeding & Jun 16 \\
\hline 29 & $\mathrm{PO}$ & Private breeders & $\begin{array}{l}\text { Field inspection and new } \\
\text { technologies }\end{array}$ & Jun 19 \\
\hline
\end{tabular}




\begin{tabular}{|c|c|c|c|c|}
\hline 30 & $\mathrm{PO}$ & Head of breeding program & $\begin{array}{l}\text { Selection of later stage } \\
\text { generations }\end{array}$ & May 17 \\
\hline 31 & $\mathrm{PO}$ & Talk in expert panel for breeders & $\begin{array}{l}\text { Farmers demands on } \\
\text { breeding goals }\end{array}$ & May 17 \\
\hline 32 & OI & Researcher at LFL & Maintenance breeding & Apr 16 \\
\hline 33 & $\mathrm{SI}^{*}$ & $\begin{array}{l}\text { Head of breeding program } \\
\text { (private) }\end{array}$ & Variety pricing & Dec 17 \\
\hline 34 & $\mathrm{SI}^{*}$ & $\begin{array}{l}\text { Head of breeding program } \\
\text { (private) }\end{array}$ & Variety pricing & Dec 19 \\
\hline 35 & $\mathrm{PO}$ & Farmer & Plant protection heuristics & Jun 19 \\
\hline 36 & OI & Cereal researcher at LFL & Breeding system & Mar 16 \\
\hline 37 & OI & Researcher in crop pathology & $\begin{array}{l}\text { Host-pathogen-human } \\
\text { interactions in cereal } \\
\text { cropping }\end{array}$ & Sep 16 \\
\hline 38 & OI & Researcher at Julius-Kühn Institut & $\begin{array}{l}\text { Resistance breeding wheat } \\
\text { diseases }\end{array}$ & Mar 17 \\
\hline 39 & OI & Researcher at Julius-Kühn Institut & Phytopathology & Jan 16 \\
\hline
\end{tabular}

